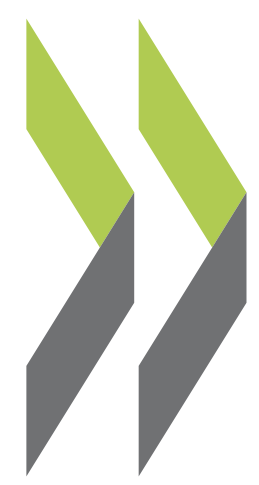

OECD Economics Department Working Papers No. 615

Public Social Spending in Korea in the Context Randall S. Jones of Rapid Population Ageing 
Organisation de Coopération et de Développement Économiques

Organisation for Economic Co-operation and Development

ECONOMICS DEPARTMENT

English - Or. English

PUBLIC SOCIAL SPENDING IN KOREA IN THE CONTEXT

OF RAPID POPULATION AGEING

ECONOMICS DEPARTMENT WORKING PAPERS No. 615

By Randall S. Jones

All OECD Economics Department Working Papers are available on the OECD Internet website at www.oecd.org/eco/working_papers

JT03245706

Document complet disponible sur OLIS dans son format d'origine

Complete document available on OLIS in its original format 


\section{ABSTRACT/RÉSUMÉ}

\section{Public social spending in Korea in the context of rapid population ageing}

Faced with exceptionally rapid population ageing, Korea should address obstacles that lower fertility rates while encouraging higher labour force participation, particularly among women. While public social spending is currently very low, there is pressure for increased outlays on pensions, healthcare, long-term care and social assistance. The government should be cautious in expanding spending, taking into account the impact on economic growth. Outlays should be limited by shifting from direct provision of social services, notably childcare and long-term care, in favour of providing vouchers to consumers. Given the limited coverage of the public pension system, the new means-tested benefit for the elderly will be useful in reducing poverty. It is important to increase transparency about self-employed income to ensure fairness in the financing of social insurance systems, including the new long-term care insurance. The rise in inequality and relative poverty should be reversed by reducing labour market dualism.

This Working Paper relates to the 2007 OECD Economic Survey of Korea (www.oecd.org/eco/surveys/korea).

JEL classification: I32, I38.

Keywords: Korea; social spending; Vision 2030 Plan; population ageing; fertility; labour force participation; National Pension Scheme; pension reform; healthcare; long-term care; income inequality; relative poverty; non-regular workers; labour market.

$* * * * * * *$

\section{Les dépenses sociales en Corée dans le contexte d'un vieillissement démographique rapide}

Confrontée à un vieillissement démographique exceptionnellement rapide, la Corée se doit d'éliminer les obstacles qui font baisser les taux de fécondité tout en encourageant l'augmentation des taux d'activité, en particulier chez les femmes. Si les dépenses sociales sont actuellement très faibles, des pressions s'exercent sur les pouvoirs publics pour qu'ils augmentent les dépenses consacrées aux retraites, à la santé, aux soins de longue durée et à l'aide sociale. L'État devra se montrer prudent en la matière, en tenant compte de l'impact de la hausse des dépenses sur la croissance économique. Pour limiter les dépenses, il devrait substituer à la fourniture directe de services sociaux - notamment dans le domaine de la garde d'enfants et des soins de longue durée - une approche fondée sur la distribution de chèques-services aux consommateurs. Compte tenu de la couverture limitée du régime public de retraite, la nouvelle prestation de vieillesse soumise à conditions de ressources devrait apporter une contribution utile au recul de la pauvreté. Il est important d'améliorer la transparence des revenus issus du travail indépendant pour garantir l'équité dans le financement des régimes d'assurance sociale, y compris le nouveau régime d'assurance des soins de longue durée. Pour enrayer la hausse des inégalités et de la pauvreté relative, il y a lieu de réduire le dualisme du marché du travail.

Ce Document de travail se rapporte à l'Étude économique de l'OCDE de Corée, 2007 (www.oecd.org/eco/etudes/corée).

Classification JEL : I32, I38.

Mots clés: Japon; dépenses sociales; programme Vision 2030; vieillissement démographique; fécondité; taux d'activité; Régime national de retraite; réforme de retraite; santé; soins de longue durée; inégalité des revenus; pauvreté relative; travailleurs non réguliers; marché du travail.

Copyright OECD 2008 Application for permission to reproduce or translate all, or part of, this material should be made to: Head of Publications Service, OECD, 2 rue André-Pascal, 75775 Paris Cedex 16, France. 


\section{TABLE OF CONTENTS}

\section{PUBLIC SOCIAL SPENDING IN KOREA IN THE CONTEXT OF RAPID POPULATION AGEING ....5}

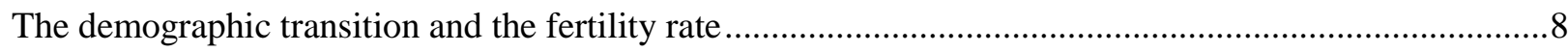

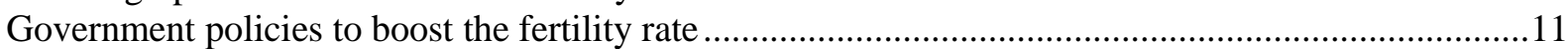

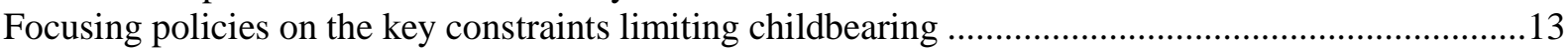

Offsetting population ageing through increasing labour force participation ......................................15

Boosting the labour force participation rate of women ......................................................................17

Making effective use of the human capital of older workers ............................................................

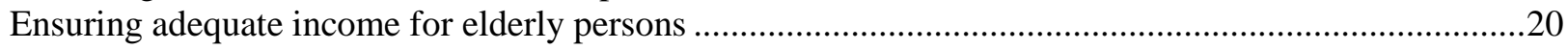

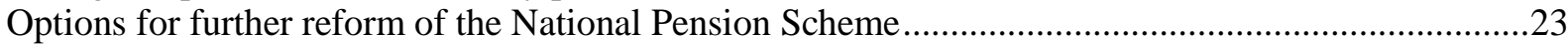

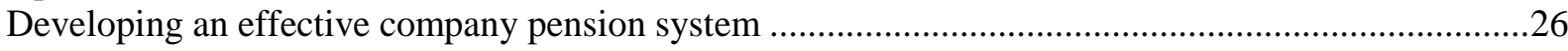

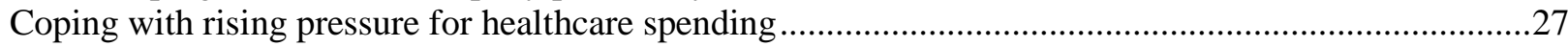

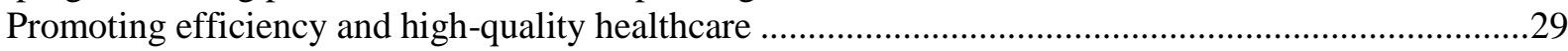

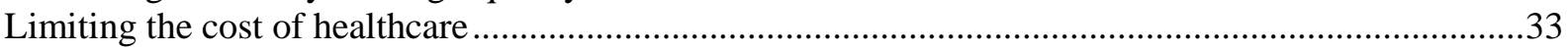

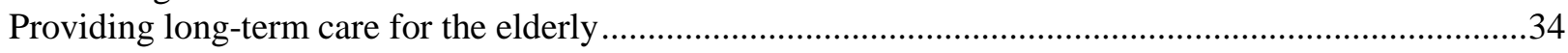

Social assistance in the context of rising relative poverty and income inequality ....................................37

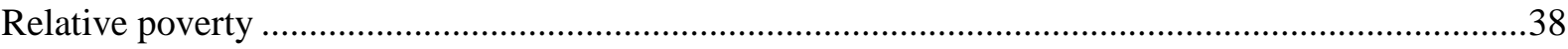

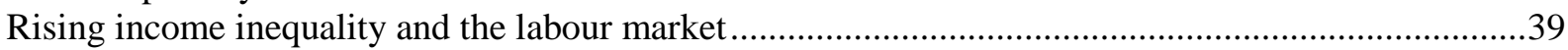

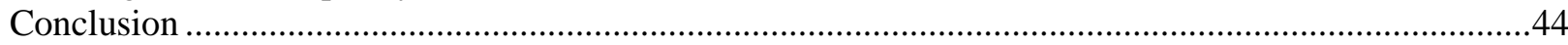

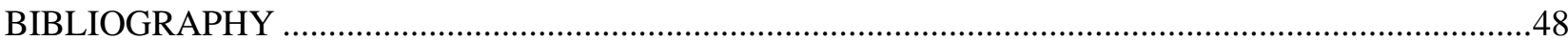

\section{Tables}

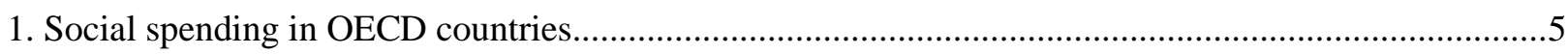

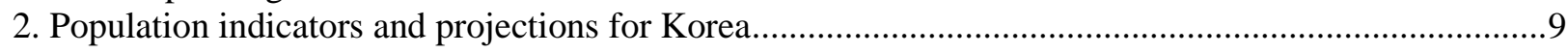

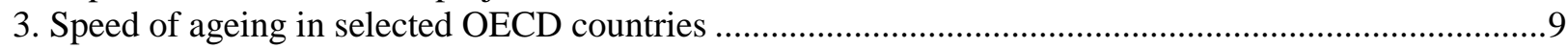

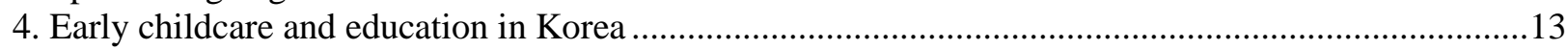

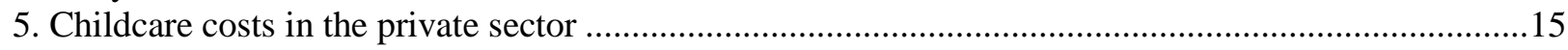

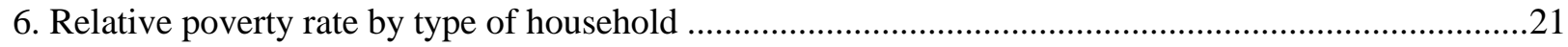

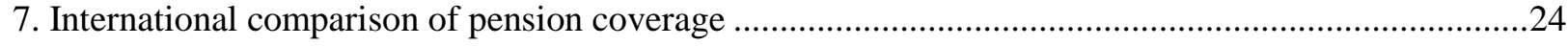

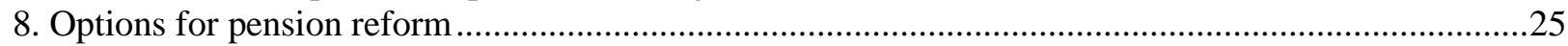

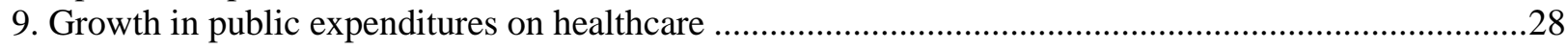

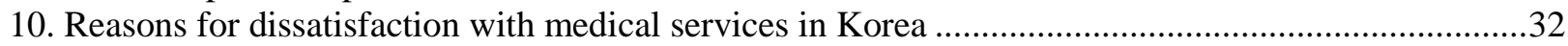

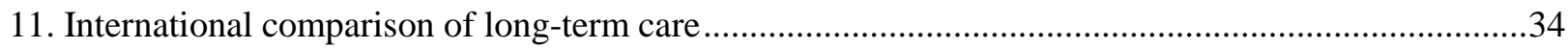

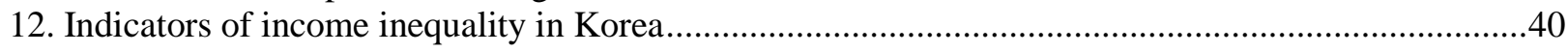

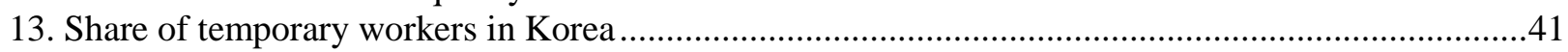

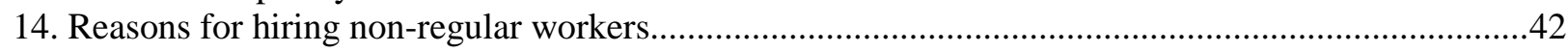

15. The coverage of social insurance and benefits by type of employment ...........................................42

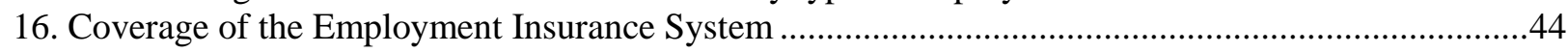

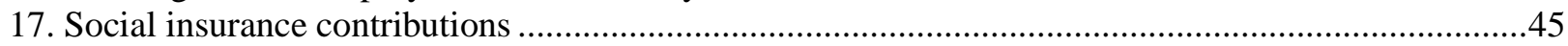




\section{Figures}

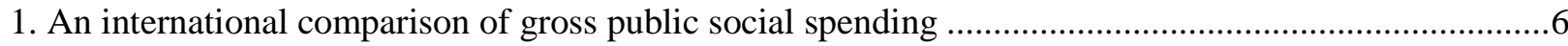

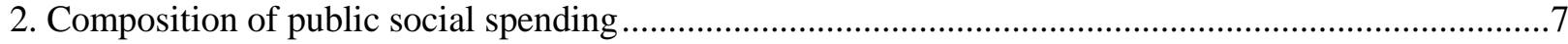

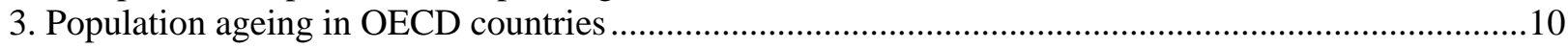

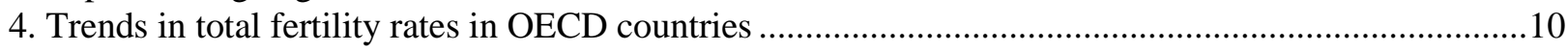

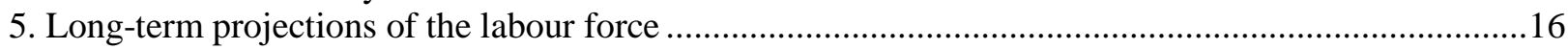

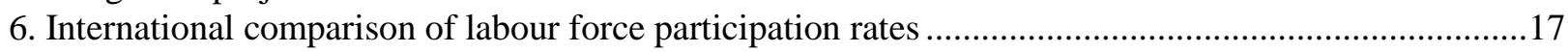

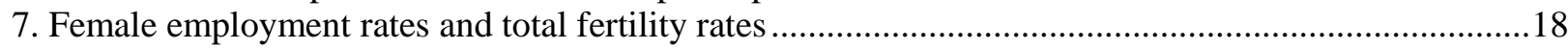

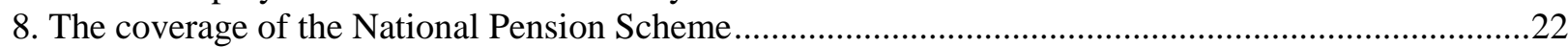

9. Projected increase in public spending on healthcare and long-term care ...........................................30

10. Evolution of Korean health expenditure by source of financing .......................................................

11. Expansion of Long-term Care Insurance in Japan ..............................................................................

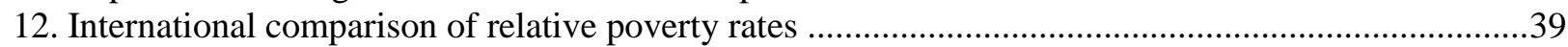

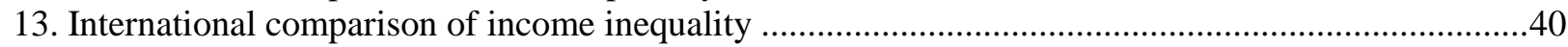

\section{Boxes}

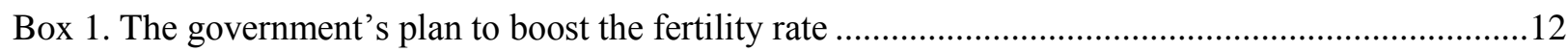

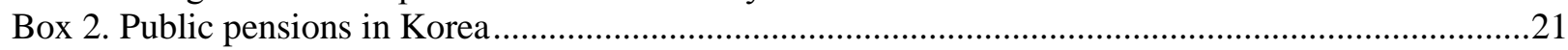

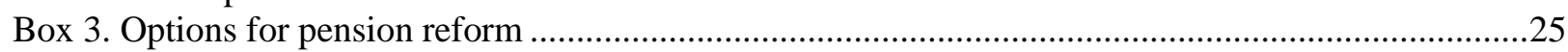

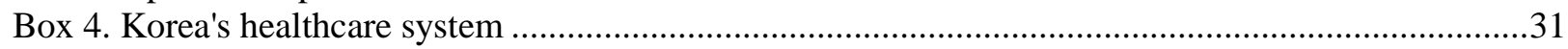

Box 5. Long-term care insurance: lessons from Japan .........................................................................36

Box 6. Summary of recommendations on public social spending in the context of ageing .....................46 


\title{
PUBLIC SOCIAL SPENDING IN KOREA IN THE CONTEXT OF RAPID POPULATION AGEING
}

\author{
By Randall S. Jones ${ }^{1}$
}

1. The development of social spending in Korea, which was still one of the poorest countries in the world only 40 years ago, is relatively recent. The key events include the introduction of a public pension system in 1988, universal health insurance in 1989 and unemployment insurance in 1995. Nevertheless, gross public social spending in Korea remained the lowest in the OECD area at $6 \%$ of GDP in 2003, well below the OECD average of $21 \%$ (Figure 1). Taking account of the impact of the tax system on social expenditure only slightly narrows the gap between Korea and the OECD average (Table 1).

Table 1. Social spending in OECD countries

Per cent of GDP, including pensions, in 2003

\begin{tabular}{|c|c|c|c|c|}
\hline Countries & $\begin{array}{l}\text { Gross public } \\
\text { spending }\end{array}$ & Net public spending ${ }^{1}$ & $\begin{array}{l}\text { Net mandatory } \\
\text { private spending }\end{array}$ & $\begin{array}{l}\text { Total net public and } \\
\text { mandatory private } \\
\text { spending }\end{array}$ \\
\hline Sweden & 31.3 & 24.2 & 0.3 & 24.5 \\
\hline France & 28.7 & 25.4 & 0.3 & 25.7 \\
\hline Denmark & 27.6 & 20.1 & 0.1 & 20.2 \\
\hline Germany & 27.6 & 26.2 & 0.6 & 26.8 \\
\hline Belgium & 26.5 & 22.9 & 0.0 & 22.9 \\
\hline Austria & 26.1 & 20.6 & 0.5 & 21.2 \\
\hline Norway & 25.1 & 20.2 & 0.9 & 21.1 \\
\hline Italy & 24.2 & 20.6 & 1.4 & 22.0 \\
\hline Portugal & 23.5 & 20.8 & 0.4 & 21.2 \\
\hline Finland & 22.5 & 17.7 & 2.1 & 19.8 \\
\hline Czech Republic & 21.1 & 19.5 & 0.2 & 19.7 \\
\hline Netherlands & 20.7 & 17.9 & 0.4 & 18.3 \\
\hline Spain & 20.3 & 17.6 & 0.0 & 17.6 \\
\hline United Kingdom & 20.1 & 18.6 & 0.6 & 19.3 \\
\hline Iceland & 18.7 & 16.6 & 3.3 & 19.9 \\
\hline New Zealand & 18.0 & 15.0 & 0.0 & 15.0 \\
\hline Australia & 17.9 & 17.0 & 2.3 & 19.3 \\
\hline Japan & 17.7 & 17.6 & 0.6 & 18.2 \\
\hline Canada & 17.3 & 17.2 & 0.0 & 17.2 \\
\hline Slovak Republic & 17.3 & 16.0 & 0.2 & 16.2 \\
\hline United States & 16.2 & 17.3 & 0.4 & 17.6 \\
\hline Ireland & 15.9 & 13.8 & 0.0 & 13.8 \\
\hline Mexico & 6.8 & 7.6 & 0.0 & 7.6 \\
\hline Korea & 5.7 & 5.9 & 1.8 & 7.8 \\
\hline OECD average & 20.7 & 18.2 & 0.7 & 18.9 \\
\hline
\end{tabular}

1. Adjusts for the impact of the tax system on social expenditure.

Source: OECD (2007), Social Expenditure Database, 1980-2003, OECD, Paris (www.oecd.org/els/social/expenditure).

1. Randall S. Jones is head of the Japan/Korea Desk in the Economics Department of the OECD. This paper is based largely on material from the OECD Economic Survey of Korea published in June 2007 under the authority of the Economic and Development Review Committee (EDRC). The author would like to thank Willem Adema, Andrew Dean, Jorgen Elmeskov, Val Koromzay, Willi Leibfritz, Monika Queisser, Tadashi Yokoyama and Taesik Yoon for valuable comments on earlier drafts. Special thanks go to Lutecia Daniel for technical assistance and to Nadine Dufour and Therese Walsh for technical preparation. 


\section{ECO/WKP(2008)23}

2. The low level of spending is explained by a number of factors. First, outlays on pensions, at only $1 \%$ of GDP, are well below the OECD average (Figure 2), reflecting Korea's relatively young population and the immature pension system. The small proportion of elderly, combined with a per capita income level that is well below the OECD average, also limits public healthcare and long-term care expenditures. Second, a low unemployment rate, averaging less than $4 \%$ of the labour force since 2000 , and the low incidence of long-term joblessness have limited spending on unemployment benefits and active labour market policies. Third, social welfare has traditionally been the responsibility of families, companies and non-governmental institutions, an approach that appeared to support rapid economic growth. Mandatory private spending amounted to $1.8 \%$ of GDP in 2003, more than double the OECD average (Table 1). In sum, combined public and mandatory private social spending in Korea, on a net basis, was $7.8 \%$ of GDP in 2003 compared to an OECD average of $18.9 \%$.

Figure 1. An international comparison of gross public social spending

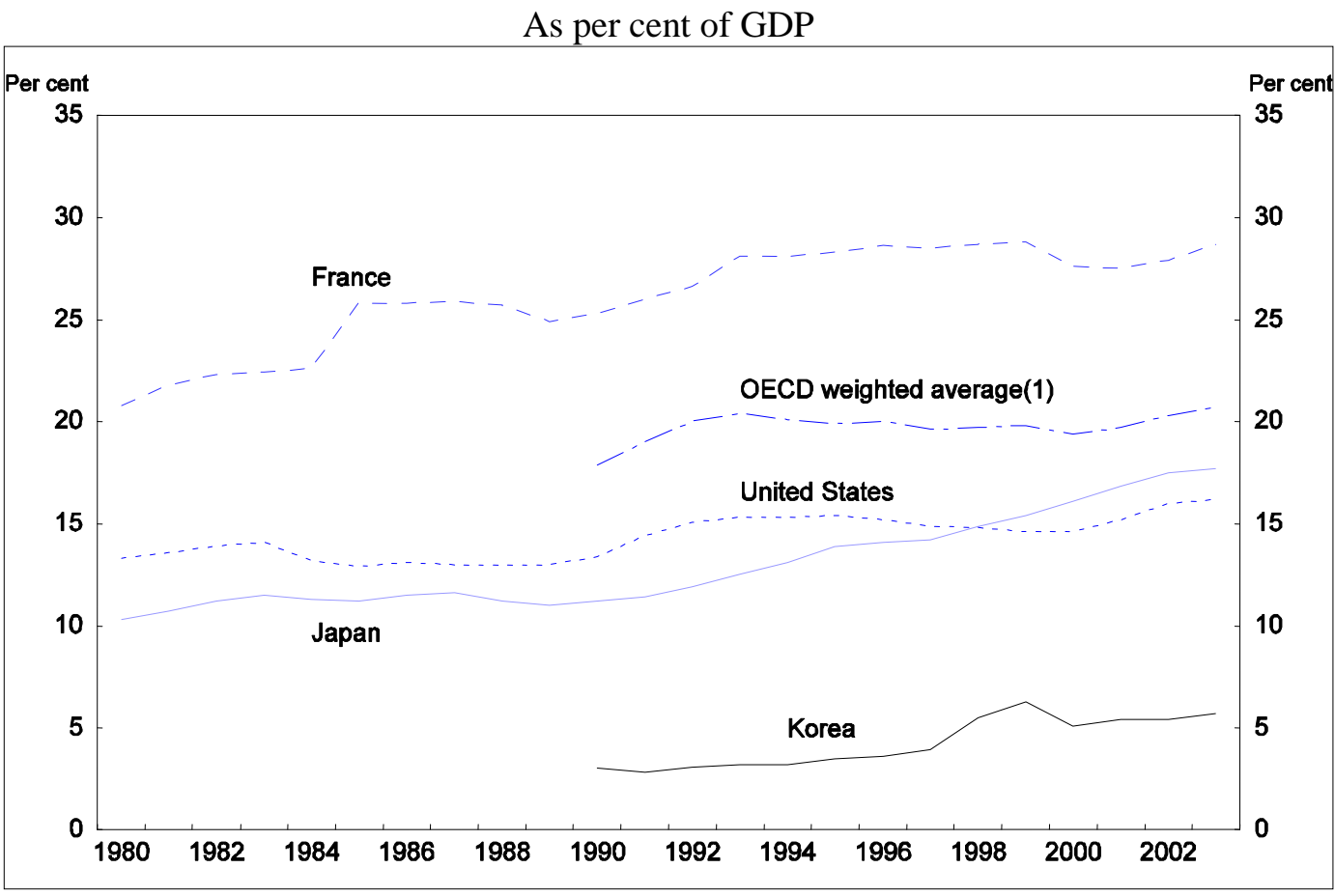

1. The OECD average does not include Hungary and the Slovak Republic due to insufficient data. The national data is converted to US dollars using 2003 PPP exchange rates.

Source: OECD, Social Expenditure Database, 1980-2003, OECD, Paris (www.oecd.org/els/social/expenditure). 
Figure 2. Composition of public social spending

Per cent of GDP in 2003

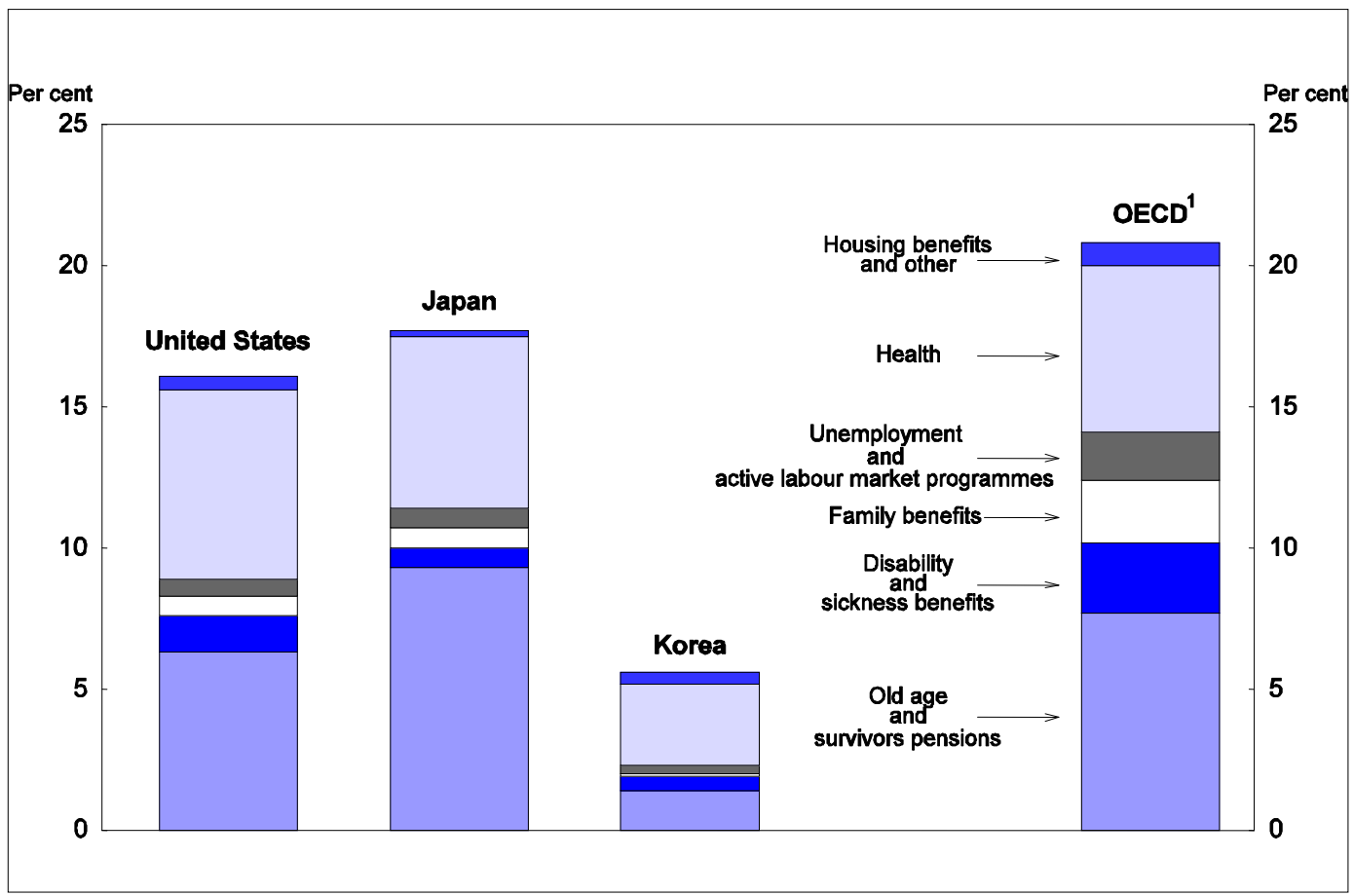

1. Weighted average of 30 countries.

Source: OECD (2007), Social Expenditure Database, 1980-2003, OECD, Paris (www.oecd.org/els/social/expenditure).

3. However, a number of factors will boost public social spending over the medium term:

- Population ageing in Korea is projected to be the most rapid in the OECD area between 2000 and 2050, increasing public expenditure on pensions, healthcare and long-term nursing care.

- Continued income gains, as Korea's per capita GDP converges to the OECD average, may stimulate demand for high-quality healthcare and long-term nursing care.

- The marked increase in income inequality and in precarious employment since the financial crisis creates pressure for larger social outlays.

- The government has announced a shift from its policies of "growth first", pursued since the mid-1960s, toward greater emphasis on the quality of life and a more equal distribution of income.

In light of these factors, the government's Vision 2030 plan (see the 2007 OECD Economic Survey of Korea) projects a rise in public social spending to the current OECD average of around $21 \%$ of GDP over the next quarter century.

4. The substantial shift of resources envisioned in the government's long-term plan suggests a need for caution. While Vision 2030 provides a roadmap for increased expenditure, it does not specify how the additional outlays should be financed. The experience of some OECD countries that are now trying to scale back public social spending in an attempt to promote efficiency and growth underlines the need to carefully design public social programmes in order to achieve their intended objectives, while avoiding or limiting wasteful spending and negative externalities. Cross-country research by the OECD suggests that increasing social protection spending accompanied by higher taxes can reduce growth, indicating a trade- 
off between efficiency and social spending. ${ }^{2}$ The negative impact is due in part to higher tax burdens, which can reduce labour supply and demand, as well as saving and capital investment. An OECD study estimates that a one percentage-point rise in the tax wedge on labour income reduces employment by $0.25 \% .^{3}$ The labour tax wedge in Korea was the fourth lowest in the OECD area in 2004 at $16 \%$ and well below the OECD average of $29 \%$, thus encouraging employment and output growth. ${ }^{4}$ Taking account of the implications of increased social spending for the tax burden and economic growth will tend to moderate plans to boost such expenditures. Korea's Vision 2030 plan emphasises developing cost-efficient and growth-friendly social programmes.

5. This paper begins with an overview of demographic trends and measures to raise the fertility rate. Policies to mitigate the impact of population ageing by raising labour force participation are discussed in the second section. The following sections examine the three major social insurance systems - public pensions, healthcare and long-term nursing care, which is to be introduced in 2008. The sixth section discusses social assistance in the context of rising income inequality and relative poverty. The paper concludes with a set of policy recommendations shown in Box 6 .

\section{The demographic transition and the fertility rate}

6. Korea's population is projected to peak at 50 million in 2020 and then decline about $15 \%$ by mid-century (Table 2). The median age, which was 20 years in 1960, reached 32 in 2000 and is likely to be nearly 50 in 2030, suggesting fundamental changes in the country's socio-economic structure. Moreover, the share of Korea's total population over the age of 65 is expected to double from $7 \%$ in 2000 to $14 \%$ by 2018 (Table 3). In contrast, this transition is projected to take 71 years in the United States and took 115 years in France. The further increase in the share of the elderly from $14 \%$ to $20 \%$ in Korea is exceptionally rapid at only eight years, compared with up to 40 years in major European countries. The rising number of older persons will boost the elderly dependency ratio from the second lowest in the OECD area in 2000 to the fourth highest by mid-century (Figure 3), the largest increase among OECD countries. This "compressed population ageing" reflects the transformation of Korea from an agrarian society to a modern, industrial state in the span of one generation.

2. A study of OECD countries estimates that raising social spending from $18.5 \%$ of GDP to $19.5 \%$ would reduce GDP in the long run by $0.7 \%$ (Arjona et al., 2001).

3. This estimate is from Bassanini and Duval (2006). Using econometric estimates to gauge the potential employment effect of policy reforms requires caution. First, the impact of a given reform differs between countries, in part because other policy settings may offset or amplify the employment effects of the reform. For instance, the increase in unemployment resulting from a rise in the tax wedge may tend to be larger when minimum wages are high, or when wage bargaining takes place at a sectoral and/or regional level. Second, the impact of a reform on unemployment is implicitly assumed to be a linear function of the policy change. This assumption holds only insofar as large reforms are comparable in nature to smaller ones.

4. The tax wedge measures the difference between total labour compensation paid by the employer and the net take-home pay of employees as a ratio of total labour compensation. The international comparison of tax wedges is based on a couple earning $100 \%$ of average worker earnings, using the average of three family situations (OECD Taxing Wages database). 
ECO/WKP(2008)23

Table 2. Population indicators and projections for Korea ${ }^{1}$

\begin{tabular}{ccccccc}
\hline & $\begin{array}{c}\text { Population } \\
\text { (in millions) }\end{array}$ & $\begin{array}{c}\text { Growth rate } \\
\text { (Per cent) }\end{array}$ & Fertility rate ${ }^{3}$ & $\begin{array}{c}\text { Life } \\
\text { expectancy } \\
\text { (in years) }\end{array}$ & $\begin{array}{c}\text { Median age } \\
\text { (in years) }\end{array}$ & $\begin{array}{c}\text { Share of } \\
\text { elderly } \\
\text { (Per cent) }\end{array}$ \\
\cline { 2 - 6 } 1960 & 25.0 & 2.3 & 6.0 & 55.3 & 19.9 & 2.9 \\
1970 & 31.5 & 1.8 & 4.5 & 63.2 & 19.0 & 3.1 \\
1980 & 37.4 & 1.5 & 2.7 & 65.8 & 22.2 & 3.8 \\
1990 & 43.4 & 0.6 & 1.6 & 71.3 & 27.0 & 5.1 \\
2000 & 46.1 & 0.6 & 1.5 & 75.9 & 31.8 & 7.3 \\
2010 & 49.2 & 0.1 & 1.2 & 79.1 & 37.9 & 10.9 \\
2020 & 50.0 & -0.1 & 1.2 & 81.0 & 43.7 & 15.7 \\
2030 & 49.3 & -0.5 & 1.3 & 81.9 & 49.0 & 24.1 \\
2040 & 46.7 & -1.0 & 1.3 & 82.6 & 53.1 & 32.0 \\
2050 & 42.3 &.. & 1.3 & 83.3 & 56.2 & 37.3 \\
\hline
\end{tabular}

1. Projections by the Korea National Statistical Office for the period 2005 to 2050.

2. The annual average growth rate for the decade. The figure in 1960, for example, shows the rate for the decade 1960 to 1970 .

3. The average number of children that a woman can expect to bear during her lifetime.

4. The number of persons over the age of 65 as a percentage of the total population.

Source: Korea National Statistical Office.

Table 3. Speed of ageing in selected OECD countries

\begin{tabular}{lccc|cr}
\hline & \multicolumn{2}{c|}{ Year when share of elderly (over age 65) make up: } & \multicolumn{2}{c}{ Years elapsed } \\
\cline { 2 - 5 } Country & $\begin{array}{c}7 \% \text { of } \\
\text { population }\end{array}$ & $\begin{array}{c}14 \% \text { of } \\
\text { population }\end{array}$ & $\begin{array}{c}20 \% \text { of } \\
\text { population }\end{array}$ & 7 to 14\% & 14 to 20\% \\
\hline Korea & $\mathbf{2 0 0 0}$ & $\mathbf{2 0 1 8}$ & $\mathbf{2 0 2 6}$ & $\mathbf{1 8}$ & $\mathbf{8}$ \\
Japan & 1970 & 1994 & 2006 & 24 & 12 \\
Germany & 1932 & 1972 & 2012 & 40 & 40 \\
United Kingdom & 1929 & 1976 & 2021 & 47 & 45 \\
Italy & 1927 & 1988 & 2007 & 61 & 19 \\
United States & 1942 & 2013 & 2028 & 71 & 15 \\
Sweden & 1887 & 1972 & 2012 & 85 & 40 \\
France & 1864 & 1979 & 2020 & 115 & 41 \\
\hline
\end{tabular}

Source: United Nations.

7. Increasing life expectancy and falling fertility is driving population ageing. Life expectancy increased 21 years, from 55 years in 1960 to 76 years in 2000 (Table 2), the largest in the OECD area. A more important factor is the fall in the fertility rate - the average number of children a woman can expect to bear during her lifetime. It fell from six children in 1960 to below the replacement level in 1983 and further to 1.5 in 2000 (Figure 4), reflecting long-term trends such as rising labour force participation of women and changing social values. ${ }^{5}$ The decline continued with a $25 \%$ drop in the fertility rate between 2000 and 2005, to 1.08, the lowest level in the OECD area. The extent of the fall is unprecedented among OECD countries and may reflect heightened economic uncertainty in the wake of the 1997 financial crisis. ${ }^{6}$ Indeed, the average age of marriage for women increased from 25.5 years in 1990 to 27.7 years in 2005, as young people seek greater financial security prior to starting families. The age of marriage is a key determinant of fertility as only $1 \%$ of births in Korea occur out of wedlock. The fall in the fertility rate to an exceptionally low level will have serious negative consequences in the long term.

5. The introduction of a national family planning programme in 1962 to lower the birthrate contributed to the rapid decline (Cho, 2006). The various regulations in the programme were finally removed in 1996.

6. A number of studies have found that a higher unemployment rate lowers fertility rates by increasing income uncertainty. See Adsera (2004). 
Figure 3. Population ageing in OECD countries

Population aged 65 and over, relative to the population aged 20-64

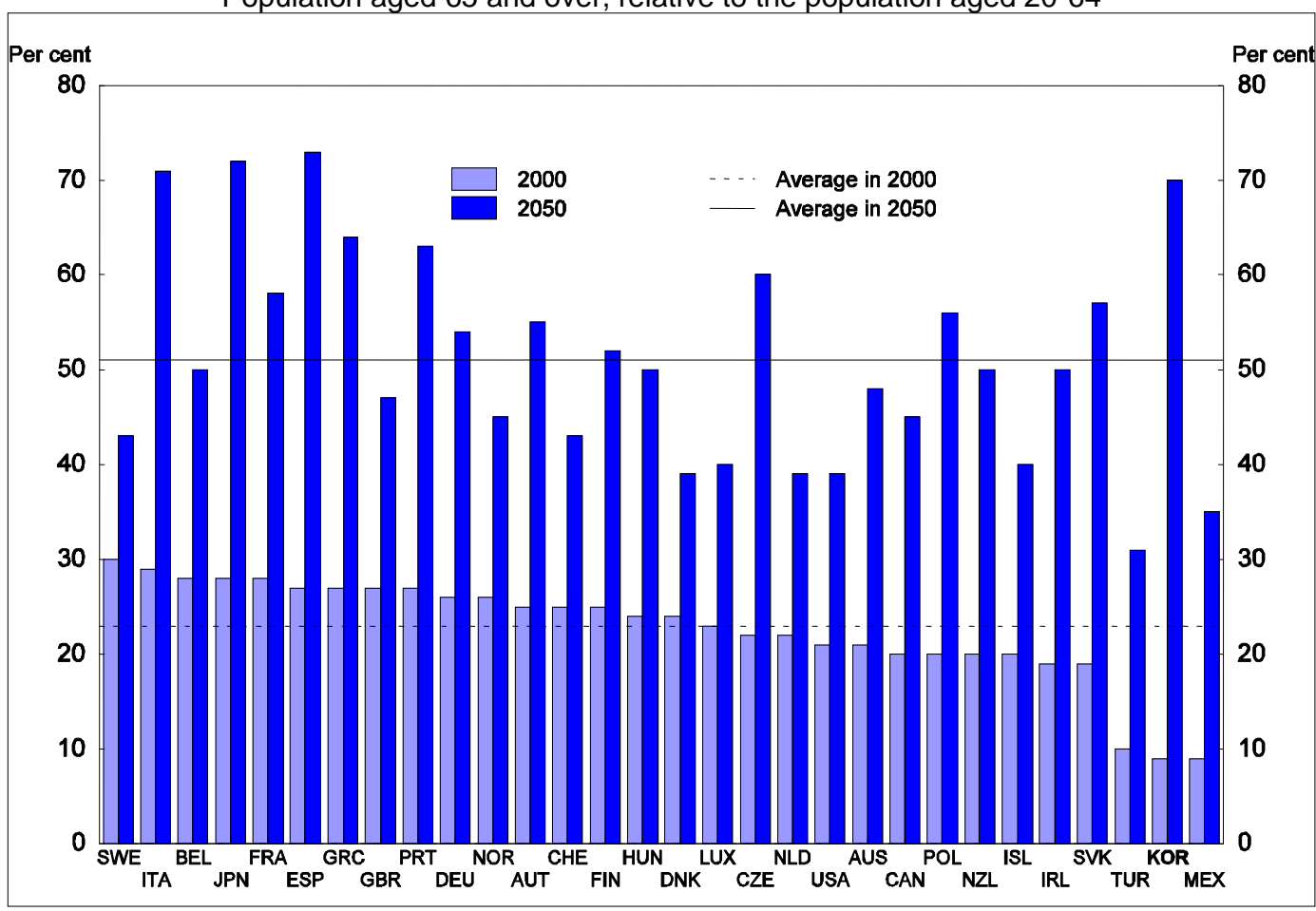

Source: OECD (2006e), Society at a Glance: OECD Social Indicators, OECD, Paris.

Figure 4. Trends in total fertility rates in OECD countries Children per woman

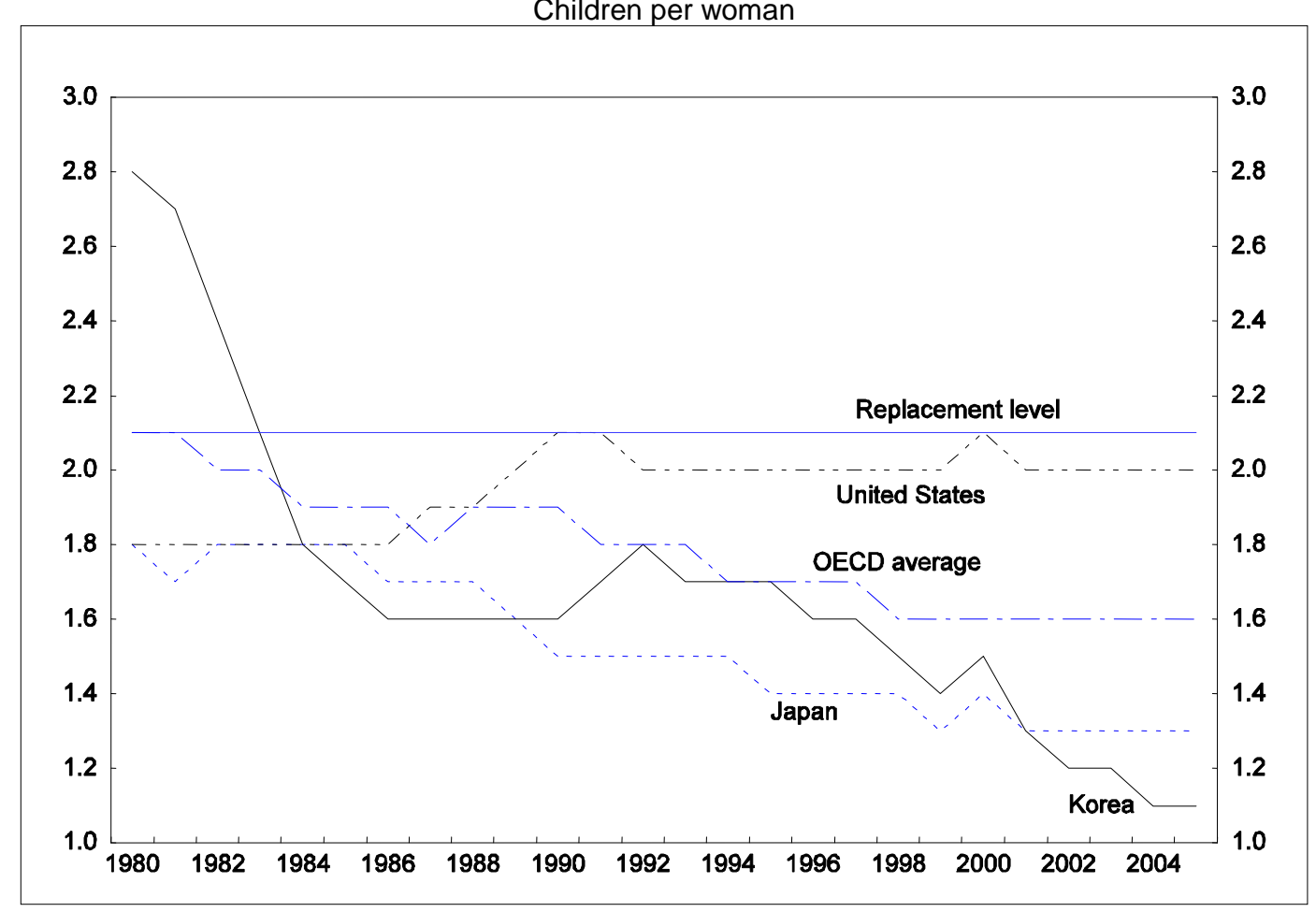

Source: D'Addio and Mira d'Ercole (2005). 
8. Some of the decline in fertility in recent years may be temporary, reflecting the trend toward later marriage and childbirth. However, a study of OECD countries concluded that the fall in birth rates over the past few decades is unlikely to be fully reversed in the medium term (d'Addio and Mira d'Ercole, 2005). Korea's official population projections assume that the fertility rate will rebound to 1.3 by 2030 and then remain at that level. However, the government has set a target of increasing the fertility rate to the OECD average of around 1.6 by 2020 . Accomplishing this goal requires an understanding of the causes of the decline and the factors that influence fertility.

\section{Government policies to boost the fertility rate}

9. According to a 2005 government survey, $59 \%$ of Korean women would like to have two children, while $34 \%$ would like three or more, with an average of 2.3 . Women thus have one child less on average than they would like to have, suggesting that there are constraints that discourage childbirth. Raising the fertility rate thus requires policies to relax these constraints. The cost of raising children appears to be an important factor in the case of Korea. In a 2005 government survey of married women between the ages of 20 and 44 with at least one child, more than half cited education as the largest item in the household budget, absorbing $18 \%$ of household income on average. One-third of the women surveyed did not plan to have more children because of the high cost of education. ${ }^{7}$ A second factor limiting the birth rate is the difficulty of combining childrearing and work. Research by the OECD has found that the fertility rate is higher in countries where parental leave is longer and childcare enrolment rates are higher (d'Addio and Mira d'Ercole, 2005). Other factors include a lack of suitable housing (see Jones and Yokoyama, 2007). To achieve its goal of raising the birthrate, the government announced a five-year plan for the period 2006-10 (Box 1).

7. Education costs amounted to $12 \%$ of spending in households with one child, $22 \%$ in those with two children and $26 \%$ in those with three or more. The proportion of women who do not want more children because of education costs excludes those who responded that they have enough children or were too old, thus limiting the sample to women who want to have additional children. See KIHASA, Ministry of Health and Welfare and the Presidential Committee on Aging Society and Population Policy (2005). 


\section{Box 1. The government's plan to boost the fertility rate}

In 2005, the government created the Committee on Low Fertility and Population Aging Policy, which is chaired by the President of Korea, to guide the preparation of a basic plan on demographic issues every five years. According to the plan announced in 2006, the government intends to spend 32 trillion won ( $0.8 \%$ of GDP per year) over the period 2006-10. The main objectives are to alleviate the burden of bearing and caring for children, while creating more familyfriendly workplaces to reduce obstacles facing women who wish to combine paid employment and childrearing.

\section{Alleviate the burden of childcare}

- Increase the coverage of income-tested support for childcare and education of children under the age of 5. At present, the government provides a benefit for children in households with an income less than the average urban household. In 2006, 0.6 million children (half of the 0 to 4 age group) received payments, which averaged 270 thousand won per month (14\% of the average wage). The eligibility is to be expanded to households with an income of up to $130 \%$ of the average income by 2009 , increasing the coverage from $50 \%$ to $80 \%$ of children.

- Expand the role of primary schools in childcare. The proportion of primary schools providing care for students is to be increased from $20 \%$ to $100 \%$ by 2010 and the availability of after-school activities is to be encouraged, thus reducing the burden of childcare on families and the need to enrol children in private tutoring institutes (hakwon)

- Improve the treatment of families with children in social insurance programmes. First, the criteria for assessing health insurance payments will be reformed to remove disadvantages for families with two or more children. Higher premium rates are still imposed for the second child and above. Second, the National Pension Scheme will allow "childbirth credits" worth one year of contributions for the second child and 18 months for the third child onward (up to a ceiling of 50 months).

- $\quad$ Provide preferential treatment in housing, including public mortgage loans and rental housing, to families with three or more children.

In addition, the government is considering the introduction of a "child allowance system" and measures to favour households with at least two children in future tax reform initiatives. At present, the income tax offers very small incentives to have children. In 2005 , the tax burden on a two-earner couple with two children amounted to $16 \%$ of labour costs, only slightly less than the $16.4 \%$ if they had no children. ${ }^{1}$ The average tax wedge in the OECD area is reduced by 4.3 percentage points, from $34.3 \%$ to $30 \%$, for a couple with two children.

\section{Combining work and family responsibilities}

- "Provide quality, public childcare services" by increasing investment in public childcare facilities to boost their share of children in institution-based care from $11.2 \%$ in 2005 (Table 4) to $30 \%$.

- Introduce a subsidy to private-sector facilities that care for children up to age 2. To ensure the quality of such services, an accreditation system was introduced in 2005 based on an assessment carried out every three years.

- $\quad$ Encourage flexible working schedules, including shorter hours for parents with childcare responsibilities.

- $\quad$ Promote family-friendly workplaces by providing rewards, certification and financial incentives to firms with good practices.

- Make parental leave more flexible and generous. Beginning in 2008, parents will be entitled to one year of leave to care for children up to age 3 (previously up to age 1). In 2007, the benefits for parental leave will be raised by a quarter to 0.5 million won per month (25\% of the average wage). The number of workers taking parental leave is low in Korea - only 10500 in 2005 - about one-quarter the number of women taking maternity leave. Moreover, men accounted for only $2 \%$ of those taking parental leave. 
Paid maternity leave is provided for 90 days, with 60 days financed by firms and the remaining 30 days by the Employment Insurance System (EIS). Beginning in 2006, EIS covers the entire 90 days for women employed in SMEs.

Table 4. Early childcare and education in Korea

A. Enrolments in childcare facilities (June 2006)

\begin{tabular}{|c|c|c|c|c|c|c|}
\hline & \multicolumn{2}{|c|}{ Facilities } & \multicolumn{2}{|c|}{ Children (thousands) } & \multicolumn{2}{|c|}{ Staff (thousands) } \\
\hline & Number & Per cent & Number & Per cent & Number & Per cent \\
\hline Public & 1507 & 5.2 & 112.7 & 11.2 & 14.4 & 9.6 \\
\hline Private, non-profit & 1484 & 5.2 & 121.4 & 12.1 & 16.3 & 10.9 \\
\hline Corporate & 975 & 3.5 & 55.3 & 5.5 & 8.2 & 5.5 \\
\hline Individual & 12860 & 44.7 & 566.1 & 56.2 & 76.5 & 51.2 \\
\hline Parent & 49 & 0.2 & 1.1 & 0.1 & 0.3 & 0.2 \\
\hline Homecare & 11575 & 40.2 & 136.2 & 13.5 & 31.6 & 21.1 \\
\hline Work-place based & 291 & 1.0 & 14.0 & 1.4 & 2.3 & 1.5 \\
\hline Total & 28761 & 100.0 & 1006.8 & 100.0 & 149.5 & 100.0 \\
\hline
\end{tabular}

B. Enrolment in childcare centres and kindergartens (thousand children in June 2006)

\begin{tabular}{|c|c|c|c|c|c|c|c|}
\hline \multirow[b]{2}{*}{ Age } & \multirow{2}{*}{$\begin{array}{c}\text { Total } \\
\text { number of } \\
\text { children }\end{array}$} & \multicolumn{2}{|c|}{ Childcare centres } & \multicolumn{2}{|c|}{ Kindergartens } & \multicolumn{2}{|c|}{ Total enrolled } \\
\hline & & $\begin{array}{l}\text { Number of } \\
\text { children }\end{array}$ & Per cent & $\begin{array}{l}\text { Number of } \\
\text { children }\end{array}$ & Per cent & $\begin{array}{l}\text { Number of } \\
\text { children }\end{array}$ & Per cent \\
\hline $0-2$ years & 1436.2 & 305.6 & 21.3 & 0 & 0.0 & 305.6 & 21.3 \\
\hline 3 years & 513.9 & 226.7 & 44.1 & 74.8 & 14.6 & 301.5 & 58.7 \\
\hline 4 years & 594.8 & 220.3 & 37.0 & 177.0 & 29.8 & 397.3 & 66.8 \\
\hline 5 years & 613.9 & 254.2 & 41.4 & 289.8 & 47.2 & 544.0 & 88.6 \\
\hline Total & 3153.5 & 1006.8 & 31.9 & 541.6 & 17.1 & 1548.4 & 49.0 \\
\hline
\end{tabular}

Source: Ministry of Education and Human Resource Development and Ministry of Gender Equality and Family.

1. This measure, taken from the OECD's Taxing Wages, refers to income tax plus employee and employer contributions, less cash benefits, as a per cent of total labour costs. It assumes a two-earner household, earning $100 \%$ and $33 \%$ of the average wage.

\section{Focusing policies on the key constraints limiting childbearing}

10. The government's plan to expand income-tested support for childcare and education of children under the age of five and to reform healthcare insurance should have a positive impact on fertility by reducing the direct cost of children. ${ }^{8}$ However, the amount is rather modest compared to the high and rising overall cost of education, which as noted above, absorbs almost one-fifth of income in households with children. The authorities should address the issue of education costs directly to reduce this constraint on childbearing decisions, while at the same time improving the quality of the school system.

11. The 2005 OECD Economic Survey of Korea discussed a number of problems linked to the private, after-school tutoring institutes known as hakwon. First, they compete and overlap with public education, thus raising total expenditures on education unnecessarily. Second, the high burden of private tutoring hinders equal access to educational opportunities, raising equity issues. Third, they make it

8. However, increasing child allowances may reduce female labour supply through its income effect. 
difficult for the public education system to cope with students of widely differing educational levels. Fourth, they create very long days for children, thus hindering their full development. The top priority should be to reduce expenditures on private tutoring, which is regarded by Koreans as a social disease that has a number of negative consequences. Several studies indicate that the high reliance on private tutoring is related to the low quality of schools (Taejong Kim, 2004) and dissatisfaction with the public education system (Hyunjin Kim, 2004). Structural reforms that bring decision-making power and accountability closer to those who teach and manage schools would enhance quality, while increasing the scope for independent schools. There are only six such schools at present. In addition, the heavy reliance on standardised university entrance exams encourages reliance on after-school tutoring of students to gain admission to the best institutions. Allowing universities more autonomy in selecting applicants would reduce reliance on hakwon. The revision of the college admission system starting in 2008, which will give more weight to performance in school and less weight to the standardised test, may help reduce the importance of hakwon.

12. A second issue is the high cost of tertiary education, reflecting the low level of public funding. Indeed, government expenditure on tertiary education amounted to less than $\$ 1000$ per student (at PPP exchange rates) in 2002, compared to an OECD average of around $\$ 8000$. Consequently, most of the cost is borne by households. With the rate of advancement from secondary to tertiary education rising from $33 \%$ of the age cohort in 1990 to $81 \%$ in 2004, a university education is considered almost mandatory by Korean parents. The projected $11 \%$ decline in the number of persons under the age of 19 over the next five years should allow a rebalancing of public outlays on education from primary and secondary level education (3.3\% of GDP) to tertiary education $(0.3 \%)$. Increased public spending on tertiary education would reduce the burden on parents while reversing the decline in the quality of the university system that accompanied its rapid expansion.

13. The government's plans to increase the compatibility of female paid employment and childcare should have a positive effect on fertility. Many women who wish to pursue a career are reluctant to have any children. One factor that enables women to combine employment and parenthood is the availability of childcare for pre-school children. In the OECD area, the proportion of children enrolled in childcare facilities has a positive effect on fertility rates (d'Addio and Mira d'Ercole, 2005). In Korea, the proportion of children enrolled in childcare is $21 \%$ for the 0 to 2 age group and $72 \%$ in the 3 to 5 age group (Table 4), close to the OECD averages of $25 \%$ and $73 \%$, respectively. Moreover, the cost of childcare is relatively low. Childcare for two children (aged 2 and 3) in a public facility costs $1.8 \%$ of gross household income compared to an average of $2 \%$ in the OECD area, while the cost of privately-provided childcare is limited by price ceilings.

14. Overall, there is not a shortage of childcare, given the vacancy ratio of $16 \%$ (see the 2005 OECD Economic Survey of Korea). Nevertheless, a 2004 survey reported that 23\% of women did not work "because they could not find a credible childcare facility". 9 The proportion of children under the age of six in childcare institutions would thus be higher if more high-quality care were available. The government plans to expand publicly-provided childcare in order to triple the proportion of children under the age of six in public facilities to $30 \%$ (see Box 1), a goal that will be expensive to achieve. Improving the availability of private childcare could be more efficiently achieved by granting earmarked support to parents. A number of countries, including Australia and the United States, have found success in using a system of childcare vouchers. Other countries, such as Canada, Germany and the United Kingdom, use tax credits and cash benefits to reimburse documented expenses. Shifting government funding from supplying childcare services to providing vouchers to families would foster competition among providers and give

9. Provided by the Ministry of Gender Equality and Family in response to an OECD questionnaire. 
more choice for parents. ${ }^{10}$ It can attract new funding and greater dynamism while limiting the outlays of governments (OECD, 2006a). Concerns about quality can be met by requiring that support for parents be used for childcare provided by licensed facilities.

15. Achieving the benefits of competition requires lifting the price ceilings imposed on private childcare services. For a child less than one year old, the ceiling is set at 361000 won (\$378) per month, with the government providing an additional 292000 won (Table 5). The combined amount (653 000 won) is well below the 789000 won that the government calculates is necessary to provide adequate care. This gap reduces the provision of childcare by private providers. It is not surprising, therefore, that a significant proportion of parents cannot find suitable childcare. The government argues that the price ceiling is needed to prevent a rise in the cost of childcare to households. However, the impact on low-income households could be offset in the vouchers provided to households, a less expensive approach than the current plan to build public childcare facilities.

Table 5. Childcare costs in the private sector Thousand won per month in 2007

\begin{tabular}{lcrr}
\hline \multicolumn{1}{c}{ Age } & 0 to 1 years & 1 to 2 years & 2 to 3 years \\
\hline Price ceiling on fees & 361 & 317 & 262 \\
Government subsidy $^{1}$ & 292 & 134 & 86 \\
Total & 653 & 451 & 348 \\
Cost of adequate care $^{2}$ & 789 & 524 & 403 \\
Shortfall & 136 & 73 & 55 \\
\hline
\end{tabular}

1. To private childcare facilities.

2. Calculated by the Government.

Source: Government of Korea (2006), Seromachi Plan 2010.

16. However, additional spending on childcare can only be effective in raising fertility rates if workplace practices change so that parents can combine careers with children. In particular, the average working time is around 2350 hours per year, 37\% above the OECD average. More than three-quarters of Korean women work longer than 40 hours per week, while $86 \%$ of men work more than 40 hours per week, reflecting in part the pro-work incentives of low marginal tax rates. The practice of unpaid overtime and long commutes in urban areas further lengthen working days. Finally, part-time employment, which is useful in balancing employment and family responsibilities in many countries, is relatively low in Korea, at $13 \%$ of female employees, compared to an OECD average of $26 \%$. In sum, implementing family-friendly policies in the public sector and encouraging their introduction in the private sector is a key priority.

\section{Offsetting population ageing through increasing labour force participation}

17. While boosting the fertility rate would slow the pace of population ageing and the burden on the working-age population, it would not be sufficient to prevent a significant decline in the labour force in the first half of this century. According to the government's population projections, the labour force would fall by $28 \%$ between 2020 and 2050 if participation rates for each age group were to remain at their current levels (Figure 5). Increasing the overall participation rate, which is below the OECD average, is important

10. In Australia, childcare providers have become more flexible in their opening hours and allow parents to buy childcare for varying time periods that match their needs (Pearson and Martin, 2005). However, given that commercial providers may not choose to invest in low-income or remote areas, there may be a need for publicly supplied childcare. 
Figure 5. Long-term projections of the labour force

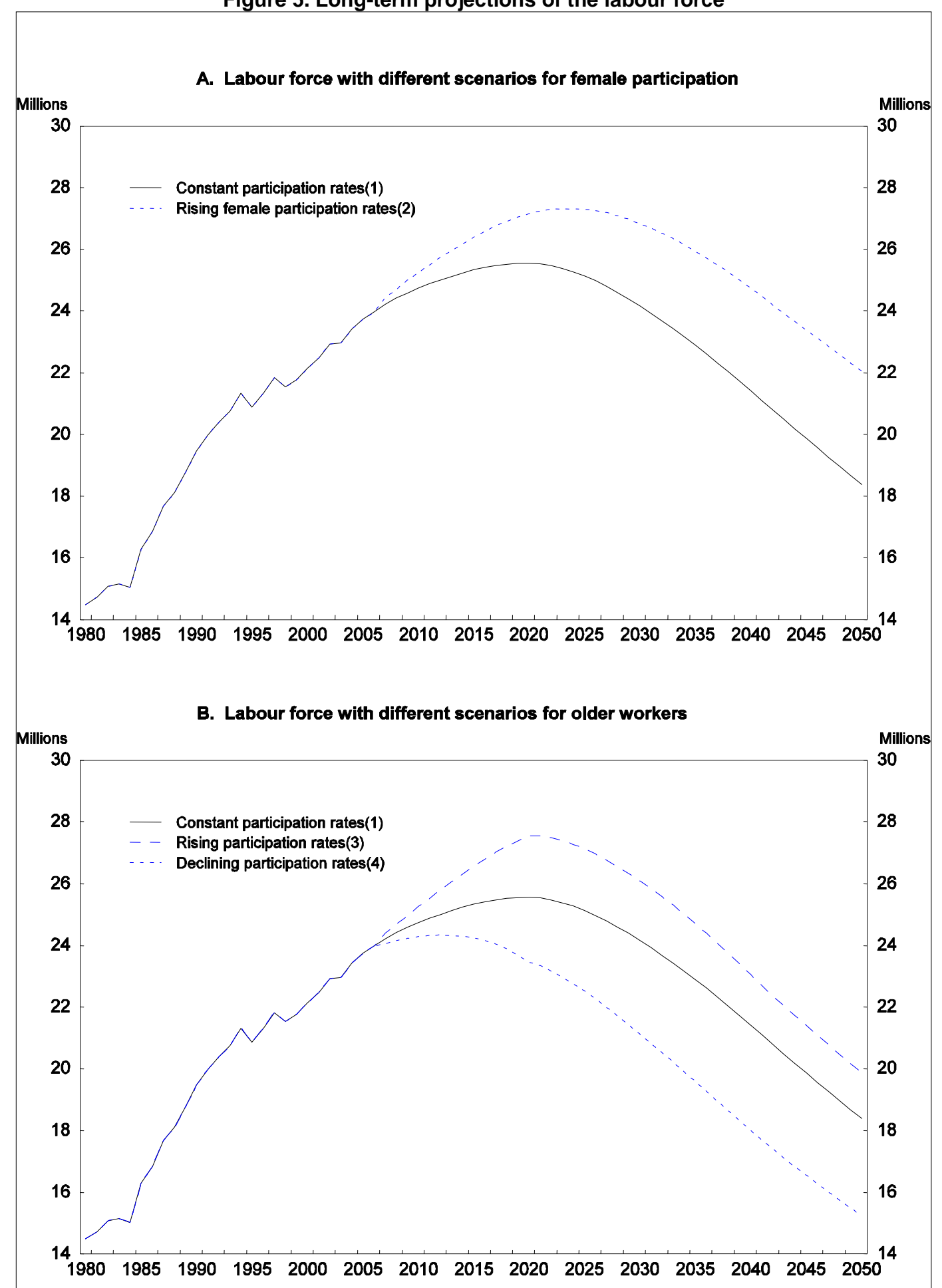

1. The participation rates for men and women remain at their current levels for each age group.

2. Female participation rates reach current male rates in each age group by 2050 .

3. The participation rates converge by 2030 to the maximum value in the OECD for each gender and age group over 50, while the rates for younger workers remain at their current levels.

4. The participation rates converge by 2030 to the average value in the OECD for each gender and age group over 50, while the rates for younger workers remain at their current levels.

Source: OECD calculations based on population projections by the Korea National Statistical Office. 
to cope with population ageing. The remaining scope for increasing the participation rate appears to be primarily among prime-age women in Korea, who have the third lowest rate in the OECD area (Figure 6). Consequently, the gap between the male and female employment rates is one of the highest in the OECD area at 23 percentage points. Another priority is to raise the age of retirement from firms.

Figure 6. International comparison of labour force participation rates

Per cent, $2005^{1}$

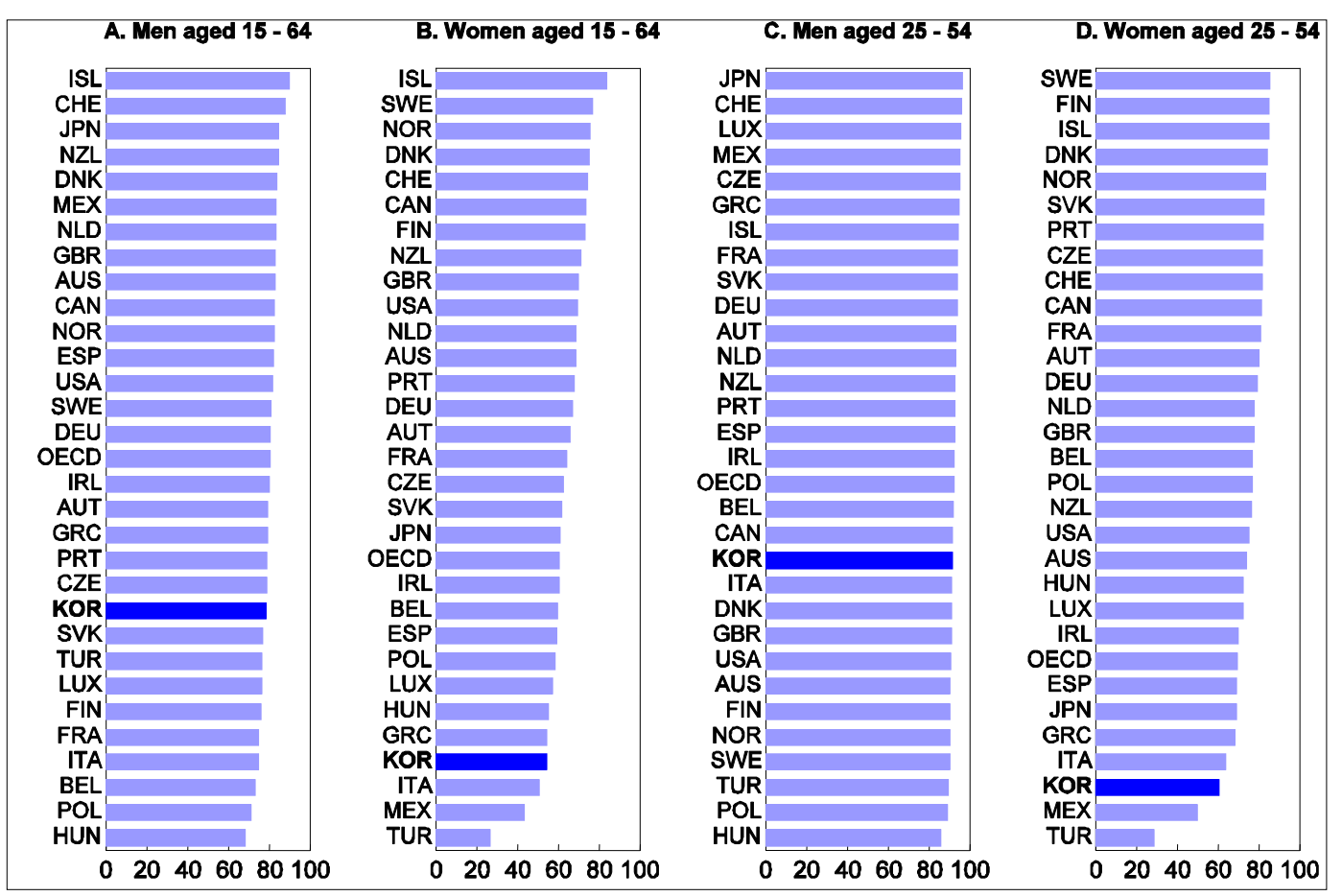

1. For the Netherlands and Sweden, data are available only for 2004.

Source: OECD (2006c), Employment Outlook, OECD, Paris.

\section{Boosting the labour force participation rate of women}

18. If the participation rate for women were to increase to the same level as for men by mid-century, the labour force in 2050 would be $20 \%$ higher than in the case of unchanged participation (Figure 5). Female employment is limited by the fact that a significant proportion of women withdraws from the labour force at the time of childbirth. Consequently, the life-time participation pattern of women is M-shaped, with peaks in the 20 to 24 and 45 to 49 age groups (see the 2005 OECD Economic Survey of Korea). Consequently, the female employment rate, at $52.5 \%$, is well below the OECD average of $60 \%$. There is a high opportunity cost attached to not fully using women's skills in the labour force. Indeed, $97 \%$ of women in the 25 to 34 age group in Korea have finished at least upper secondary school, the highest proportion in the OECD area.

19. The experience of countries such as the United States and New Zealand, which have fertility rates of two and female employment rates close to $70 \%$, demonstrates that it is possible to combine high fertility and high female employment (Figure 7). The correlation between female employment and fertility rates in the OECD area is significantly positive. For Korea, the policies discussed above to boost fertility rates by encouraging family-friendly policies in the business sector and expanding the availability of affordable childcare will tend to raise both fertility and participation rates. Indeed, in a 2006 government survey, 46\% 
of women cited childcare as the chief obstacle to female labour force participation. ${ }^{11}$ Paid parental leave and childcare subsidies have been found to have a significantly positive impact on female participation rates in other OECD countries (Jaumotte, 2003). Compared to the OECD average of five months, paid maternity leave in Korea is 90 days and there is some question about its effective coverage. Indeed, the average maternity benefit per birth in Korea in 2002 was only $3 \%$ of the average production workers' wage, one of the lowest benefit levels in the OECD area and well below the average of $42 \%$ (d'Addio and Mira d'Ercole, 2005). On the other hand, providing tax and social benefits for families with children, as suggested in the government's five-year plan, has been found to lower female participation in other OECD countries. Transfers to families with children, therefore, should be aimed at reducing child poverty, rather than boosting the fertility rate.

Figure 7. Female employment rates and total fertility rates

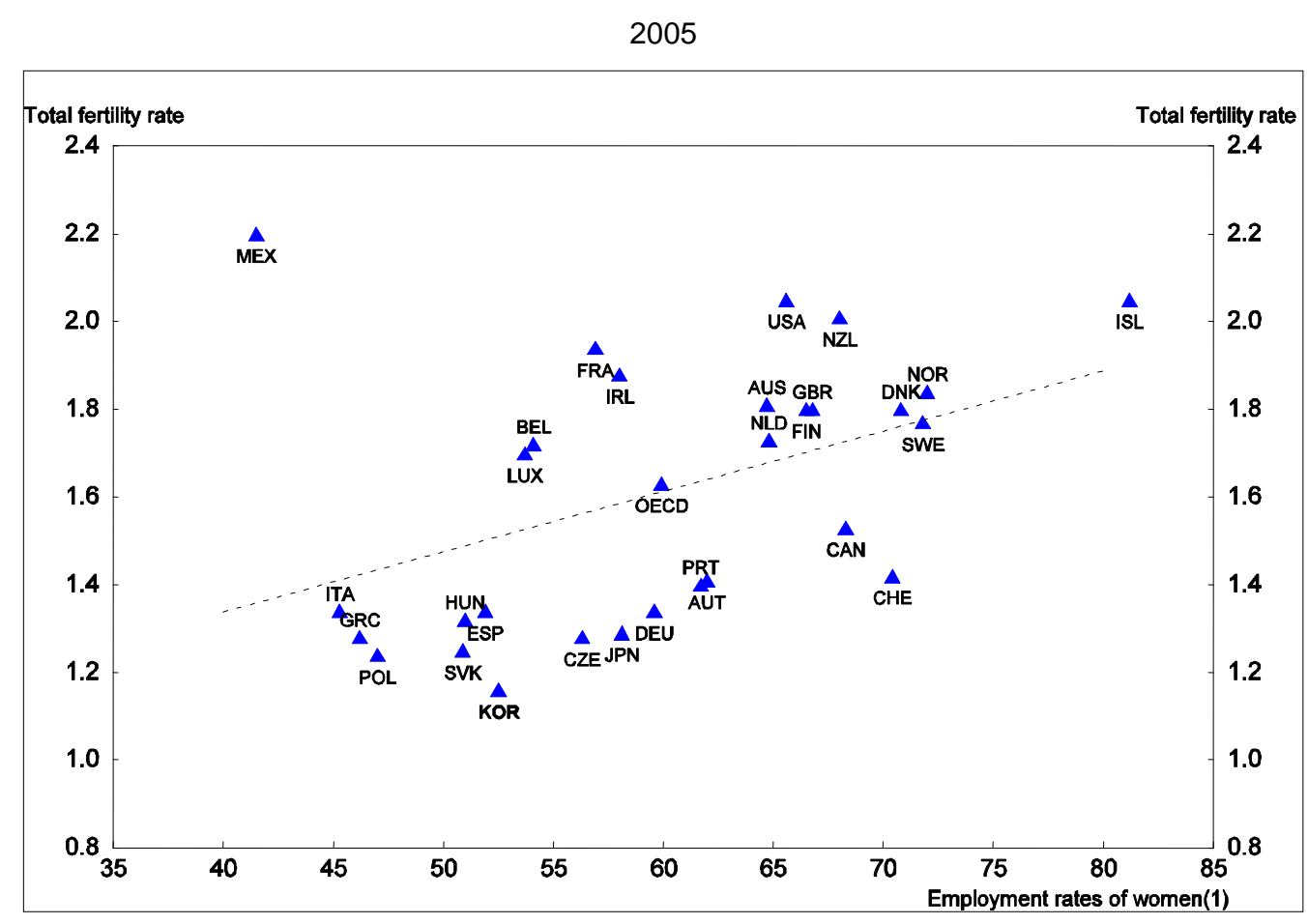

1. Refers to women aged 15-64.

Source: OECD (2006e), Society at a Glance: OECD Social indicators, OECD, Paris.

20. In addition to facilitating female employment and childrearing, there is the question of attracting mothers who have left jobs back into the labour force once their children are older. Incentives to return to work are weakened by labour market conditions, including the large gender wage gap, which at $40 \%$ in 2003, is more than double the OECD average of $18 \% .^{12}$ The wide gap reflects a number of factors. First, although women make up $38 \%$ of the workforce, their share of managerial jobs is only $8 \%$, compared to 20-30\% in many OECD countries (OECD, 2007a). Second, the tradition of seniority-based wages rewards workers with long tenures. As a result, women who interrupt their careers for children are locked into low salaries regardless of their performance. Third, the high and rising proportion of non-regular workers, who

11. Korea National Statistical Office (2006). The other major obstacles were social prejudice against working women $(18.5 \%)$, unfair labour conditions $(11.6 \%)$ and the burden of housework $(7.2 \%)$.

12. After adjusting for workers' characteristics, the gender gap in wages is estimated at about $20 \%$ for regular workers (Jeong, 2003). 
receive significantly lower salaries and benefits (see below), limits opportunities for women, as the incidence of non-regular employment is nearly twice as high for women. Even women employed as regular workers prior to interrupting their careers for children find it difficult to return as regular workers (Hwang and Chang, 2004).

21. Unattractive employment options encourage many women to remain out of the labour market. Indeed, Korea is the only OECD country in which the employment rate of female university graduates $(57 \%)$ is less than the rate for women with less than an upper secondary education (59\%). In contrast, the average employment rate for female university graduates in the OECD area, at 79\%, is significantly higher than the $49 \%$ rate for women with less than an upper secondary education. Creating better opportunities for women requires reversing the rising trend of non-regular workers, while encouraging the use of performance-based pay in place of the seniority-based system. In addition, OECD experience indicates that paid maternity leave of up to five months is ideal in terms of female labour force participation, suggesting that the three months currently provided in Korea should be lengthened.

\section{Making effective use of the human capital of older workers}

22. While almost half of the population is under the age of 30 at present, more than half will be over the age of 50 by 2030 and over age 56 by the middle of the century, according to government projections. Consequently, the size of the labour force will depend critically on the participation rate of older persons. As noted earlier, the labour force would decline by more than a quarter between 2020 and 2050 if participation rates were to remain at their current levels (Figure 5). The decline could be limited to $22 \%$ if the participation rate for the 50 to 64 age group were to increase to the maximum level recorded in the OECD area in 2000 (Panel B). On the other hand, the labour force would decline $40 \%$ from its 2020 peak if the participation rate for older workers were to decrease to the OECD average. Unlike most other OECD countries, Korea has not experienced a decline in participation rates for older workers. Indeed, the rate remains relatively high for men in the 50 to 64 age group and for both men and women over 65, reflecting in part the early stage of development of the pension system. Older persons thus depend to a large degree on employment, as well as transfers from family members, for support. The sensitivity of the size of the labour force in 2050 to the participation rate of older workers demonstrates the importance of policies to encourage those over age 50 to remain economically active in order to increase or at least maintain their participation rate. ${ }^{13}$

23. In addition, it is important to use the human capital of older workers more effectively. At present, employees tend to leave firms around the age of 50, a relatively young age in a rapidly ageing economy. Indeed, the average employment tenure peaks at 11 years in the 45 to 49 age group - well below most other OECD countries where the peak is in the 55 to 64 age group - and then falls sharply (see the 2005 OECD Economic Survey of Korea). The early departure of employees reflects the importance of seniority rather than individual performance - in determining wage levels. Most firms set a mandatory retirement age, generally well below the age of 60 recommended by law, to avoid being burdened by a large number of expensive older workers. Given the difficulty of dismissing regular employees, a mandatory retirement age also helps firms to adjust their workforces (Cho and Lee, 2005). About three-quarters of departing

13. In February 2007, the government announced its " $2+5$ Strategy", which aims to reduce the preparation period prior to entering the labour force by two years and to encourage people to stay in the labour force for an additional five years. To accomplish the latter objective, the government will: 1) take policy initiatives to expand job description and performance-based wage systems; 2) reform the National Pension Scheme by further reducing the Early Old-age Pension (which is available from age 55) and further increasing the Later Old-age Pension (which is available from age 60); and 3) encourage a longer work period through the introduction of the Retirement Extension Allowance and by preventing age discrimination. Under the Retirement Extension Allowance, employers who extend the employment of older workers receive 0.3 million won per worker during half of the employment extension. 
employees become self-employed, primarily in sectors characterised by low productivity and income. Consequently, $40 \%$ of workers over the age of 55 are self-employed, compared to only $27 \%$ of those under that age. Of those who continue as employees past the age of 50, the majority work as non-regular workers in small firms.

24. Older self-employed persons tend to work in sectors, such as agriculture and retail, which are facing significant structural change. However, as the average education level of older persons increases over time, they may become less interested in accepting self-employment and jobs at small companies offering significantly lower salaries. Consequently, the pattern of employees leaving firms at a relatively young age may have an increasingly negative impact on the participation rate in the future. It is thus important to encourage greater flexibility in wages within firms so that older workers do not become too expensive. Requiring companies to set the age for mandatory retirement at an age closer to the pension eligibility age - or forbidding the use of mandatory retirement altogether - would be beneficial. Firms accept the seniority-based wage systems demanded by employees on the condition that they can force older workers to leave once their productivity no longer matches their pay. Without mandatory retirement, companies would insist on wage systems that more closely reflect productivity. In addition, the retirement allowance system (see below), which increases the cost of keeping older workers, needs to be reformed. Finally, the National Pension Scheme should be closely monitored as it matures to avoid providing incentives for early retirement.

25. The relatively low level of education of older persons is a major challenge to their participation in the labour force. Indeed, two-thirds of unemployed persons over the age of 50 failed to complete secondary school, leaving them behind in Korea's increasingly knowledge-based economy. Three-quarters worked previously as daily or temporary workers (Chang, 2004). Government expenditures on lifelong learning, including vocational training, amounted to only 0.8 trillion won $(0.1 \%$ of GDP) in 2004 . The participation rate of adults in lifelong education is $23 \%$, which is in the lower group of OECD countries. Moreover, the rate for those who failed to complete secondary school is less than $10 \%$. More emphasis on lifelong learning and training would likely improve the employment prospects of older workers.

26. Lifelong learning may be more effective than the employment subsidies offered by the government. The number of workers covered by three different subsidies to encourage firms to hire and retain older worker rose from 88 thousand in 1996 to more than 250 thousand in 2004 (see the 2005 OECD Economic Survey of Korea). Real estate service firms account for about two-thirds of the companies receiving subsidies, with the majority concentrated in building maintenance services. The concentration of the subsidies in one business line raises doubts as to their effectiveness in boosting the overall employment of older workers. Indeed, $92 \%$ of firms receiving the subsidy responded that they would have hired the same number of workers in the absence of any assistance (Chang, 2004). This is consistent with results in other OECD countries showing deadweight costs as high as 90\% (Martin and Grubb, 2001).

\section{Ensuring adequate income for elderly persons}

27. The relative poverty rate - based on an income threshold of $40 \%$ of the national median - for households that include elderly persons has risen from $27 \%$ in 1991 to $38.8 \%$ in 2000, nearly five times higher than the $8.1 \%$ national average (Table 6). In contrast, the average relative poverty rate for the elderly in the OECD area, at $13 \%$ in 2000 , was not far above the average of $10 \%$ for the total population. ${ }^{14}$ There has been a weakening of the tradition of three-generation households in Korea. In 2005, elderly persons living alone or with a spouse accounted for 55\% of households with an elderly person. In contrast, the share of elderly persons living with one of their children was only $39 \%$. Still, three-quarters of the elderly receive financial support from their children, while one quarter earns income from their own and/or

14. This is based on a poverty threshold set at $50 \%$ of the national median. 
their spouse's employment. Pension income still plays a minor role: only $14 \%$ of the elderly receive public pensions, reflecting the relatively recent introduction of the National Pension Scheme (Box 2). In addition, 9\% receive social assistance (Korea Institute for Health and Social Affairs, 2006).

Table 6. Relative poverty rate by type of household

Threshold for relative poverty rate is $40 \%$ of median income

\begin{tabular}{lrrr}
\hline & 1991 & 1996 & 2000 \\
\cline { 2 - 4 } A. Relative poverty rate & & & 4.9 \\
Couple households & 3.8 & 2.4 & 38.8 \\
Elderly households & 27.0 & 40.3 & 14.6 \\
Female-headed households & 13.1 & 11.0 & 11.6 \\
Male-headed households & 7.1 & 6.0 & 16.4 \\
Single-person households & 7.1 & 9.4 & 8.1 \\
Total households & 5.0 & 4.6 & 82.8 \\
B. Demographic structure & & & 6.7 \\
Couple households & 88.3 & 84.9 & 5.0 \\
Elderly households & 2.9 & 3.6 & 3.4 \\
Female-headed households & 4.3 & 5.4 & 3.1 \\
Male-headed households & 2.7 & 3.2 & 100.0 \\
Single-person households & 1.8 & 100.0 & \\
\hline Total households & 100.0 & & \\
\hline
\end{tabular}

Source: Ku (2004).

\section{Box 2. Public pensions in Korea}

The National Pension Scheme (NPS) was created in 1988 as a partially-funded system with a strong redistributive element, as benefits are based equally on the average wage in the economy and individual earnings. In effect, all beneficiaries with 40 years of contributions will receive a basic pension equivalent to $30 \%$ of the average wage, with the remainder of the benefit determined by the individual's earnings. In setting pension benefits, average earnings, based on the three-year average of all insured persons during the three years immediately prior to retirement, are valorised in line with prices and the benefit is indexed to prices after retirement.

The coverage of the NPS was initially limited to regular employees in firms with at least ten workers. Compulsory coverage has been gradually expanded to include all workplaces and types of employees and the self-employed. Consequently, the number of persons paying contributions increased from 4.4 million in 1988 to 12.8 million in 2006, $53 \%$ of the labour force (Figure 8). Payment of the full NPS old-age pension will only begin in 2008, once the initial participants meet the minimum twenty years of contributions. However, the government is already paying benefits to 1.4 million persons who receive other types of NPS pensions, ${ }^{1}$ although total payments are small at $0.3 \%$ of GDP.

The government is required to review the sustainability of the NPS every five years. Although the NPS is less than 20 years old, it has already been revised several times. The pension benefit accrual rate was initially set at $1.75 \%$ a year, implying a replacement rate of $70 \%$ for an average income worker with 40 years of contributions. Even though the initial contribution rate of $3 \%$ was doubled to $6 \%$ in 1993 , benefits remained too high relative to contributions. In 1998, the NPS was reformed by reducing the average replacement rate to $60 \%$ (an accrual rate of $1.5 \%$ ) and raising the contribution rate to $9 \%$. Under these parameters, the scheme would have moved into deficit in 2036, exhausting the National Pension Fund by 2047. Ensuring financial sustainability - defined as a reserve fund large enough to pay two years of benefits - through 2070 would have required boosting the contribution rate to nearly $20 \%$ by 2030 .

A bill was introduced in the National Assembly in 2003 to reduce the replacement rate from $60 \%$ to $50 \%$ in 2008 , accompanied by a rise in the contribution rate to $15.9 \%$ by 2030 . However, this proposal was blocked by the National Assembly. Finally, in December 2006, a compromise was approved by a committee in the National Assembly to lower the replacement rate to $50 \%$ (an annual accrual rate of $1.25 \%$ ), while boosting the contribution rate to $12.9 \%$ by 2018 . This bill, though, was also rejected by the National Assembly in April 2007. This reform would have delayed the depletion of the National Pension Fund from 2047 to 2065. However, ensuring the long-run financial sustainability of the system under the planned contribution rate of $12.9 \%$ would have required a reduction of the replacement rate to $40 \%{ }^{2}$ In 2008 , the government will introduce a means-tested benefit equal to $5 \%$ of the average wage. Initially, $60 \%$ of the elderly will be eligible for this means-tested benefit, with total payments amounting to $0.3 \%$ of GDP initially. 
Korea is one of only three countries with a pension eligibility age as low as 60 , although it is to be gradually increased to 65 by 2033 . ${ }^{3}$ There is a risk, though, that a significant number of workers will opt for the "early pension", which is available from age 55. It is essential to avoid incentives for early retirement, which depend on the combined effect of the replacement rate - the level of pension income relative to wage earnings - and the change in pension wealth when continuing to work. A high replacement rate encourages withdrawal from the labour force, as would a loss in net pension wealth if the person continues to work. The increase in the reduction rate from $5 \%$ to $6 \%$ per annum which lowers pension benefits to those who retire early - may reduce incentives for early retirement.

Figure 8. The coverage of the National Pension Scheme Number of contributors

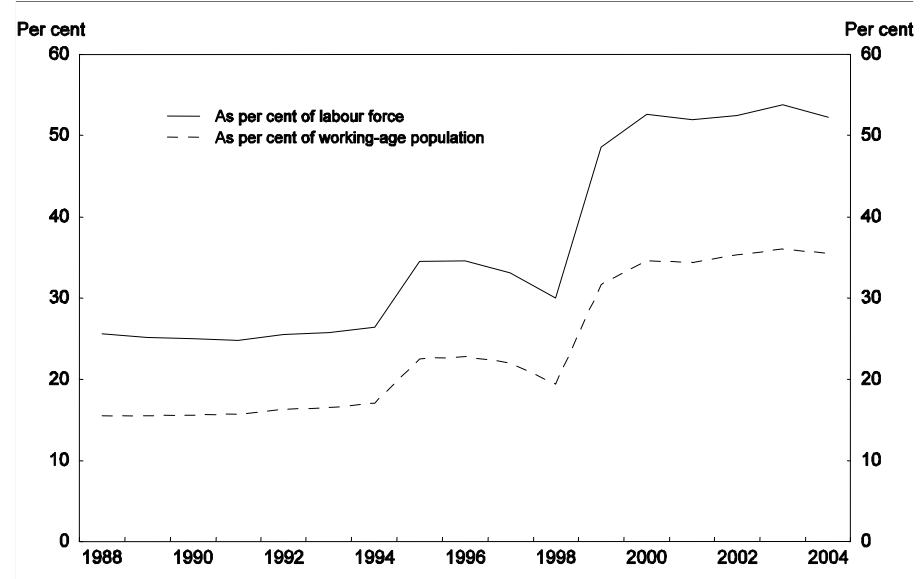

Source: National Pension Service and the Korea National Statistical Office.

It is also important to reform the occupational pension schemes established for civil servants (1960), military personnel (1963) and private-school teachers (1975). These schemes, which currently insure 1.4 million workers $(6 \%$ of the labour force), rely increasingly on government subsidies, which amounted to 1.5 trillion won in 2005 (excluding the government's contributions as an employer). The amount of subsidies is projected to rise sharply in the future, indicating the need for reform. Eliminating subsidies for the civil service pension would require boosting the contribution rate from $8.5 \%$ to $37 \%$. In addition, it is essential to address the issue of portability between the occupational schemes and the NPS.

1. These include the "special pension" (paid to persons over 60 with an insured period of at least five years), the "early pension" (over 55 and ten years insured), the "reduced pension" (over 60 and 10 to 20 years insured) and the "active pension" (persons between 60 and 64 who continue to work and have an insured term of at least ten years).

2. The political parties agreed to a compromise in April 2007 that would reduce the replacement rate from $60 \%$ to $40 \%$, while keeping the contribution rate unchanged at $9 \%$.

3. Raising the age further should be considered as one option to ensure the sustainability of the NPS without further cutting the replacement rate.

28. The maturation of the NPS will increase the income of the elderly. However, the number of contributors to the NPS leveled off at around a third of the working-age population in 2000 (Figure 8). The proportion is significantly higher for men, at half of the male working-age population, compared to only a quarter for women. Adding the occupational pension schemes for the civil service, military and privateschool teachers boosts the proportion of contributors to almost $40 \%$ of the working-age population (Table 7). However, it remains low compared to the OECD average of $63.4 \%$. The low level of coverage in Korea reflects the large number of self-employed persons and non-regular workers. The long-term 
projections of the NPS assume that less than half of the elderly will receive NPS pensions in 2030, suggesting that it does not expect a significant expansion in coverage.

29. In addition to the low level of coverage, there is a risk that pension benefits will be relatively small. In its long-term projections, the NPS assumes that the average period of contribution of beneficiaries in 2030 will be 17.6 years and will increase only gradually to 20.7 years by 2050 . With an annual accrual rate of $1 \frac{1}{2}$ per cent, the replacement rate for a worker in 2030 who had earned an average income and had 40 years of contributions, would be $26 \%$, less than half of the targeted replacement rate of $60 \%$. Such an income is close to the minimum cost of living, which is set at $20 \%$ of the average wage. If the authorities follow the option of lowering the target replacement rate to $40 \%$, the average pension in 2030 would then fall below the minimum cost of living. Moreover, there is likely to be a significant variation among beneficiaries in their contribution periods. Salaried workers would have as many as 30 years if the average age when workers leave companies rises from its current level of around age 50 to 55 . With the overall average of 17.6 years of contributions, the average contribution period for the self-employed is likely to be quite short, leaving them below the minimum cost of living. Moreover, there is a large gap in the level of contributions between those ensured through their workplace (1.9 million won in 2006) and individually-insured persons (1.05 million won), who tend to be self-employed. In sum, the low level of coverage, short average contribution period and small payments by those who are self-employed raise the risk that the NPS will not be adequate to reduce the rate of poverty among older persons.

\section{Options for further reform of the National Pension Scheme}

30. In addition to ensuring its long-run financial sustainability, reform of the NPS should focus on the effectiveness of the pension system in reducing poverty among the elderly. One option is to substantially boost the amount of contributions to the NPS and its coverage, which has stalled at around one-third of the working-age population. Achieving this objective is difficult, as noted above, because of the large number of non-regular workers and self-employed and the lack of transparency about their income. Given the uncertainty, the NPS assumes, as a general practice, that self-employed persons have the same earnings as middle-income employees, thus discouraging low-income persons from contributing to the NPS.

31. Given the difficulty of substantially extending the coverage of the NPS, the recent introduction of the means-tested benefit is a step in the right direction, although at 5\% of the average wage, it is well below the minimum cost of living ( 0.4 million won per month), which is $20 \%$ of the average wage, according to the National Basic Livelihood Security System (NBLSS). Expanding the benefit to the minimum cost of living to prevent absolute poverty and extending its coverage to all persons over the age of 65 is estimated to boost its cost from 1.1\% of GDP in 2050 to around 6.8\% (Box 3). The cost of this universal pension would be in addition to contributions to the NPS, which would reach 7\% of GDP in 2050 , based on a contribution rate of $12.9 \%$. The total cost of a universal pension and the NPS would thus rise to almost 14\% of GDP in 2050 (Table 8, Column 2). This is above the OECD average of 11\% of GDP projected for 2050 (Dang et al., 2001). A higher than average level in Korea would not be surprising given that its share of elderly will be one of the highest in the OECD area. Nevertheless, this would be a tremendous increase in public social spending. 
Table 7. International comparison of pension coverage

\begin{tabular}{|c|c|c|c|}
\hline \multirow[b]{2}{*}{ Country } & \multirow[b]{2}{*}{ Year } & \multicolumn{2}{|c|}{ Number of contributors to mandatory pension system: ${ }^{1}$} \\
\hline & & $\begin{array}{c}\text { As per cent of labour } \\
\text { force }\end{array}$ & As per cent of working-age population \\
\hline Austria & 2004 & 80.8 & 58.8 \\
\hline Belgium & 1995 & 86.2 & 65.9 \\
\hline Canada & 1992 & 91.9 & 80.2 \\
\hline Czech Republic & 2003 & 86.0 & 61.0 \\
\hline Denmark & 2003 & 92.0 & 74.0 \\
\hline Finland & 2003 & 90.3 & 67.0 \\
\hline France & 2003 & 90.0 & 62.0 \\
\hline Germany & 2003 & 88.0 & 64.0 \\
\hline Greece & 2002 & 79.0 & 52.0 \\
\hline Hungary & 1996 & 77.0 & 65.0 \\
\hline Iceland & 1993 & 92.0 & 91.0 \\
\hline Ireland & 2002 & 93.0 & 64.7 \\
\hline Italy & 2003 & 90.0 & 56.0 \\
\hline Japan & 2003 & 94.0 & 73.0 \\
\hline Korea & 2004 & 58.8 & 39.9 \\
\hline Mexico & 2002 & 34.6 & 22.6 \\
\hline Netherlands & 2002 & 94.0 & 72.0 \\
\hline Norway & 2003 & 92.0 & 75.0 \\
\hline Poland & 2005 & 84.8 & 54.5 \\
\hline Portugal & 2003 & 92.0 & 71.0 \\
\hline Slovak Republic & 2003 & 58.8 & 55.0 \\
\hline Spain & 2003 & 92.0 & 63.0 \\
\hline Sweden & 2003 & 90.0 & 72.0 \\
\hline Switzerland & 2003 & 99.0 & 84.0 \\
\hline Turkey & 2002 & 44.9 & 24.3 \\
\hline United Kingdom & 2003 & 94.0 & 73.0 \\
\hline United States & 2003 & 91.0 & 71.0 \\
\hline Average & & 83.6 & 63.4 \\
\hline
\end{tabular}

1. This table does not take into account any universal, tax-financed pensions.

Source: World Bank (2007), World Development Indicators.

32. The total cost of public pensions under the two-part approach could be reduced by further scaling back the NPS. With the development of financial markets, the rationale for government involvement in redistributing people's income over their lifetime has weakened, suggesting a greater focus on protecting the elderly against poverty. If the replacement rate of the NPS were cut to $20 \%$, the contribution rate could be reduced to $6.5 \%$ of labour income, $3.5 \%$ of GDP (Table 8 , third column). The combined replacement rate of $40 \%-20 \%$ each from the universal pension and the NPS - would cost around $10 \%$ of GDP in 2050 , close to the level projected for the OECD area. The cost could be further reduced by cutting the universal pension. If it were set at $15 \%$ of the average wage, the total cost (including the NPS) would be $8.6 \%$ of GDP in 2050 (Table 8, fourth column), well below the projected level for the OECD.

33. In sum, the Korean authorities have a choice between the current approach, which will provide a substantial public pension benefit to nearly half of the population, and systemic reform to create a two-part national system that includes a universal pension. There are advantages to each of these options. The current approach has the positive feature of requiring saving by the current working population in preparation for retirement, thus promoting inter-generational equity. The advantage of the two-part national pension is that it would prevent absolute poverty among the elderly. In terms of financing, the two-part system would rely more on tax revenue and less on social security contributions. 


\section{Box 3. Options for pension reform}

\section{A basic or universal pension}

This box tries to estimate how much it would cost to transform the means-tested benefit to be introduced in 2008 into a universal pension. The means-tested benefit will be equivalent to $5 \%$ of the average national wage and will be provided to $60 \%$ of the elderly, at a cost of $0.3 \%$ of GDP (Box 2). As the proportion of the elderly rises from $10 \%$ in 2008 to $37 \%$ by 2050 , the cost would be around $1.1 \%$ of GDP (Table 8, first column). Raising the benefit to the minimum cost of living (20\% of the average wage) and making it universal would boost the cost to $6.8 \%$ of GDP in 2050:

- Increasing the benefit from $5 \%$ of the average wage to $20 \%$, while maintaining the coverage at $60 \%$ of the elderly, would raise the total cost to $4.4 \%$ of GDP.

- Eliminating the means test to make it a universal pension would further increase the cost to around $6.8 \%$ of GDP (Table 8 , second and third columns), taking into account that $8.6 \%$ of the elderly already receive social assistance to boost their income to the minimum cost of living. ${ }^{1}$

Lowering the replacement rate to $15 \%$ would reduce the cost to $5.1 \%$ of GDP (Table 8 , fourth column).

\section{The cost of the NPS}

Under the government's reform proposal, the contribution rate would rise to $12.9 \%$ of earnings in 2018 . Assuming that it would stay at that level - sufficient to ensure the sustainability of the NPS for a replacement rate of $40 \%-$ NPS contributions would amount to $7 \%$ of GDP. ${ }^{2}$ The total cost of the NPS and the means-tested benefit would be around $8.1 \%$ of GDP in 2050 (Table 8, column 1), while transforming the benefit into a universal pension would be significantly more expensive (column 2). The cost assuming that the NPS is scaled back is shown in column 3 , while column 4 assumes that both the NPS and the universal pension are reduced.

Table 8. Options for pension reform

Projections for 2050

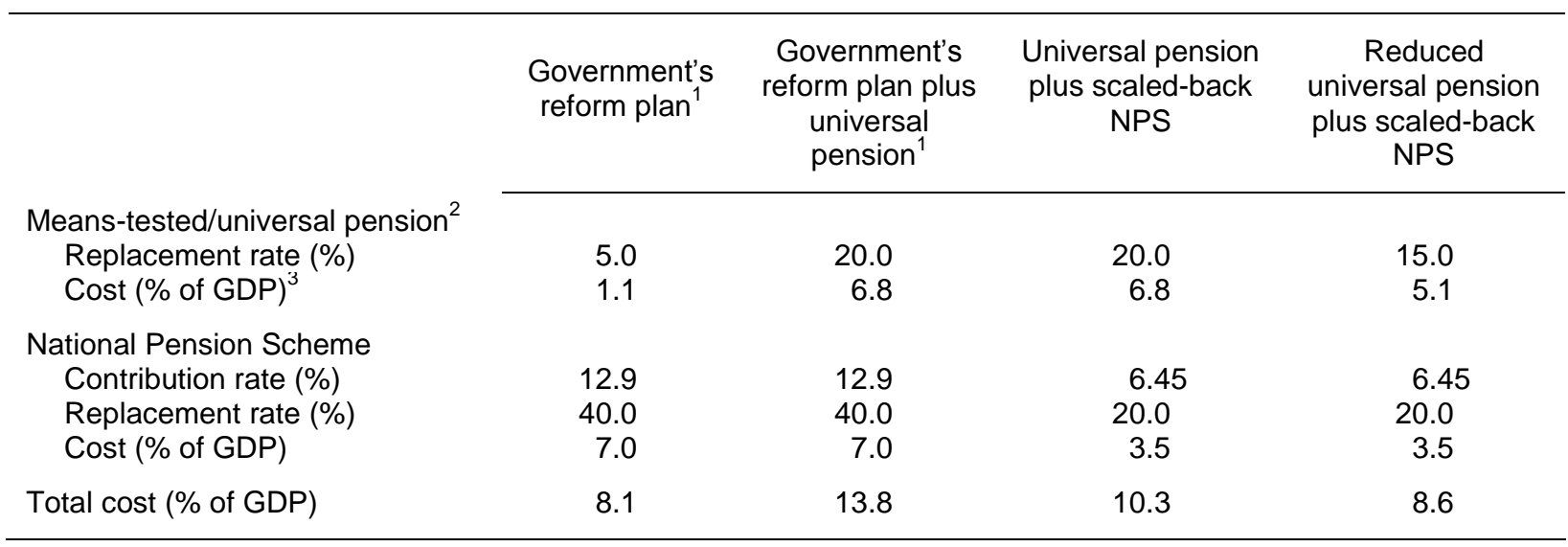

1. Under the government's reform plan, the replacement rate would be cut from $60 \%$ to $50 \%$. However, it would need to be cut to $40 \%$ (as assumed in the first two columns) to ensure the sustainability of the NPS under the proposed contribution rate of $12.9 \%$. Otherwise, the contribution rate would need to be raised to nearly $16 \%$. The cost in terms of GDP assumes that employee compensation and self-employed income - which are subject to NPS contributions - remain around $55 \%$ of GDP.

2. Both the means-tested benefit in the government's plan and a universal pension would be financed by tax revenue.

3. For the universal pension, it nets out the savings in social assistance to the elderly (currently $8.6 \%$ receive social assistance).

Source: OECD calculations.

1. There would be additional savings from eliminating the Old-age Allowance, which provides 50000 won a month to social assistance recipients over the age of 80, 45000 won to those between 65 and 80 and 35000 won to low-income elderly.

2. This does not take account of the public occupational schemes, which cover $6 \%$ of the labour force and are scheduled for fundamental reform. Table 8 assumes that everyone is covered by the NPS. 
34. The National Pension Fund amounted to 185 trillion won (23\% of GDP) in October 2006 and is projected to increase nine-fold over the next 30 years. The Fund's investment objective is to generate a high return, while taking account of "stability and socioeconomic utility". Around 91\% of the Fund is invested in bonds, with government bonds accounting for almost half of this category. Investment in equities is much less at $8 \%$ of the Fund. Further increasing the outsourcing of Fund management to private companies, which account for $8 \%$ of the total at present, may help boost returns. However, it is essential to ensure a governance framework that prevents political influence on the firms in which the Fund invests. In addition, it is important to protect the Fund from political pressure in allocating its investment portfolio.

35. Scaling back the NPS as part of a systemic reform would limit the accumulation of assets in the National Pension Fund. While this would reduce the risk associated with a large concentration of assets in a single institution, scaling back the NPS would make it even more important to encourage greater privatesector savings for retirement. One key is to develop the "company pension system" introduced in 2005.

\section{Developing an effective company pension system}

36. The company pension system was implemented in 2005 , with the following provisions:

- Workplaces with five or more employees may transform the existing lump-sum retirement allowance into a company pension, based on an agreement between labour and management. They must choose between a defined benefit and a defined contribution scheme. Firms with less than ten employees are allowed to establish individual retirement accounts (IRAs).

- Firms that adopt defined benefit schemes must entrust at least $60 \%$ of the funds to financial institutions and $100 \%$ in the case of defined contribution schemes. In both cases, the employers must provide payments at least as large as under the lump-sum retirement allowance.

By December 2006, pension plans had been introduced by more than 16000 firms (3.5\% of the total), although most of them were small companies. Indeed, $99.6 \%$ of the firms introducing pension plans had less than 500 employees. Defined contribution schemes (including individual retirement accounts) accounted for $89 \%$ of the pension plans. However, among the 59 large companies that adopted pension plans, three-quarters opted for defined benefit schemes or plans that combined defined benefits with defined contributions.

37. The low number of large firms introducing company pension plans reflects differences between employers and employees on which type of plan to introduce. Employers favour defined contribution plans, which place the risk on workers, while workers favour defined benefit plans, which are similar to the current retirement allowance in guaranteeing the amount paid. The difficult environment for collective bargaining may frustrate agreements on the type of pension plan. The government's decision to introduce a company pension system while maintaining the retirement allowance reflects the difficulty of phasing out the latter, which is popular with workers, who consider it to be deferred wage payments. Moreover, the lump sum is often used to start a small business after leaving a firm. In the absence of new government measures, the retirement allowance system may continue indefinitely given its popularity.

38. However, the retirement allowance system has a number of drawbacks. First, it creates incentives to retire employees early. Many large firms have agreed to pay about double the required one month of salary for each year worked. Given that the lump sum is based on an employee's final wage, which increases sharply with seniority, there is a disincentive to keep older employees. Second, it is not a secure source of income, as the lump-sum is partially unfunded, making full payments dependent on the firm's 
survival. Third, given the short average tenure of employees in Korea, this payment has lost its link to retirement income as most workers receive such lump sums numerous times during their working life and often spend it for housing or consumer durables. ${ }^{15}$ To promote the transition to company pensions, the government should remove the tax preferences for retirement allowances, which allow the lump sum to be taxed over a number of years at low rates. In addition, the government should encourage defined contribution systems, rather than those based on defined benefits, in order to promote pension portability and thereby labour mobility. Given that average employment tenure is only five years in Korea, an average worker may be employed by as many as eight or nine firms during his/her career, making a defined benefit system difficult to manage.

\section{Coping with rising pressure for healthcare spending}

39. Public spending on healthcare, on a per capita basis, has expanded at a $10.1 \%$ annual rate (adjusted for inflation) since 1981, well above the OECD average of 3.6\% (Table 9). The increase was largely explained by rising incomes, although demographic factors also played a role. In addition, a residual factor - primarily the shift of healthcare spending from the private to the public sector - boosted outlays by $2.4 \%$ a year. The National Health Insurance (NHI) achieved universal coverage in 1989, only 12 years after its introduction (Box 4). To limit the cost of expanded coverage, the NHI restricted benefits and set co-payments at a high level. Consequently, the private sector accounts for half of total spending on healthcare, well above the OECD average of $28 \%$. This helps to limit public healthcare expenditure to $3 \%$ of GDP, the lowest in the OECD area (Figure 9).

40. A cross-country analysis by the OECD projects that public spending on healthcare will rise by between 3 and 5 percentage points of GDP in Korea over the period to 2050, the largest increase among member countries (Figure 9). First, given the tendency for medical expenses to increase with age, rapid population ageing in Korea is projected to raise public healthcare outlays by $1.6 \%$ of GDP, double the $0.7 \%$ expected in the OECD area (OECD, 2006d). The elderly in Korea accounted for $23 \%$ of total health expenditures in 2004, well above their 9\% share of the population. Consequently, healthcare expenditure per capita was three times higher for those over 65 than for those under. Second, relatively rapid growth in income, as living standards in Korea converge to the OECD average, will tend to push up the share of national income devoted to healthcare. ${ }^{16}$ Under this assumption, the level of healthcare spending in Korea in 2050 - at $6 \%$ to $8 \%$ of GDP - would be comparable to the current level in some OECD countries, including Japan.

15. In fact, employees are allowed to receive this lump-sum payment in advance while still employed to help them finance major expenditures, including housing.

16. However, in the OECD projections, the rise in public healthcare spending is limited by the assumption that the residual factor is constant at $1 \%$ through 2050 in all member countries (cost-pressure scenario) or that it is gradually reduced to zero in all countries by 2050 (cost-containment scenario). This assumption may be less appropriate for Korea given that the private-sector share of healthcare spending is already high. 
Table 9. Growth in public expenditures on healthcare ${ }^{1}$

Average annual percentage change between 1981 and 2002 unless otherwise noted

\begin{tabular}{|c|c|c|c|c|}
\hline & $\begin{array}{l}\text { Total health } \\
\text { spending }\end{array}$ & Age effect & Income effect ${ }^{2}$ & Residual $^{3}$ \\
\hline $\begin{array}{l}\text { Australia (1981-2001) } \\
\text { Austria } \\
\text { Belgium (1985-2002) } \\
\text { Canada } \\
\text { Czech Republic (1993-2002) }\end{array}$ & $\begin{array}{l}2.6 \\
2.2 \\
2.9 \\
2.6 \\
2.7\end{array}$ & $\begin{array}{l}0.4 \\
0.1 \\
0.4 \\
0.4 \\
0.4\end{array}$ & $\begin{array}{l}1.8 \\
2.1 \\
1.7 \\
1.7 \\
2.8\end{array}$ & $\begin{array}{r}1.4 \\
0.0 \\
0.6 \\
0.6 \\
-0.4\end{array}$ \\
\hline $\begin{array}{l}\text { Denmark } \\
\text { Finland } \\
\text { France } \\
\text { Germany } \\
\text { Greece (1987-2002) }\end{array}$ & $\begin{array}{l}1.3 \\
2.6 \\
2.8 \\
2.2 \\
3.4\end{array}$ & $\begin{array}{l}0.1 \\
0.3 \\
0.2 \\
0.2 \\
0.4\end{array}$ & $\begin{array}{l}1.7 \\
2.1 \\
1.6 \\
1.2 \\
1.3\end{array}$ & $\begin{array}{r}-0.5 \\
0.2 \\
1.0 \\
1.0 \\
0.8\end{array}$ \\
\hline $\begin{array}{l}\text { Hungary (1991-2002) } \\
\text { Iceland } \\
\text { Ireland } \\
\text { Italy (1988-2002) } \\
\text { Japan (1981-2001) }\end{array}$ & $\begin{array}{l}1.5 \\
3.5 \\
3.9 \\
2.1 \\
3.8\end{array}$ & $\begin{array}{l}0.3 \\
0.1 \\
0.1 \\
0.7 \\
0.4\end{array}$ & $\begin{array}{l}2.8 \\
1.5 \\
4.9 \\
1.7 \\
2.2\end{array}$ & $\begin{array}{r}-1.5 \\
1.9 \\
-1.0 \\
-0.1 \\
1.1\end{array}$ \\
\hline $\begin{array}{l}\text { Korea (1982-2002) } \\
\text { Luxembourg (1981-2002) } \\
\text { Mexico (1990-2002) } \\
\text { Netherlands (1981-2002) } \\
\text { New Zealand }\end{array}$ & $\begin{array}{r}10.1 \\
3.8 \\
4.5 \\
2.6 \\
2.7\end{array}$ & $\begin{array}{l}1.4 \\
0.0 \\
0.7 \\
0.3 \\
0.2\end{array}$ & $\begin{array}{l}6.1 \\
3.9 \\
0.5 \\
1.9 \\
1.5\end{array}$ & $\begin{array}{r}2.4 \\
-0.1 \\
2.4 \\
0.3 \\
1.0\end{array}$ \\
\hline $\begin{array}{l}\text { Norway } \\
\text { Poland (1990-2002) } \\
\text { Portugal } \\
\text { Slovak Republic (1997-2002) } \\
\text { Spain }\end{array}$ & $\begin{array}{l}4.0 \\
3.1 \\
5.9 \\
2.1 \\
3.4\end{array}$ & $\begin{array}{l}0.1 \\
0.5 \\
0.4 \\
0.5 \\
0.3\end{array}$ & $\begin{array}{l}2.5 \\
3.2 \\
2.6 \\
4.2 \\
2.3\end{array}$ & $\begin{array}{r}1.5 \\
-0.6 \\
2.8 \\
-1.5 \\
0.8\end{array}$ \\
\hline $\begin{array}{l}\text { Sweden } \\
\text { Switzerland (1985-2002) } \\
\text { Turkey (1984-2002) } \\
\text { United Kingdom } \\
\text { United States }\end{array}$ & $\begin{array}{r}1.5 \\
3.8 \\
11.0 \\
3.4 \\
4.7\end{array}$ & $\begin{array}{l}0.1 \\
0.2 \\
0.3 \\
0.2 \\
0.1\end{array}$ & $\begin{array}{l}1.7 \\
0.8 \\
2.3 \\
2.3 \\
2.0\end{array}$ & $\begin{array}{r}-0.4 \\
2.9 \\
8.3 \\
1.0 \\
2.6\end{array}$ \\
\hline Average & 3.6 & 0.3 & 2.3 & 1.0 \\
\hline
\end{tabular}

1. Total public health spending per capita.

2. Assuming an income elasticity of health expenditure equal to 1.

3. Includes the shift of healthcare spending from the private to public sector, the cost of implementing technological advances in medical care and adverse relative price changes.

Source: OECD (2006d).

41. In contrast, the Korean authorities project a sharper increase in public healthcare spending to $12 \%$ of GDP by 2050 , which would make it the highest in the OECD area. Indeed, the rise in healthcare expenditures may be significantly larger than projected in Figure 9 for a number of reasons. Perhaps most importantly, total healthcare outlays, at $6 \%$ of GDP in 2005, are relatively low compared to the level of per capita income in Korea, in part due to the practice of keeping price increases in the healthcare sector below overall inflation. This creates pressure for catch-up in the price of healthcare services that would boost its share of GDP. In addition, the low level of healthcare outlays at present reflects the impact of high 
out-of-pocket payments that restrict demand. ${ }^{17}$ Given that the share of healthcare spending borne by the private sector is already high, there is little scope for controlling public outlays by shifting more of the burden to the private sector. The government instead plans to increase its share of healthcare financing from $50 \%$ to $60 \%$ over the next few years. ${ }^{18}$ It is important to ensure that out-of-pocket payments do not limit access to healthcare. While out-of-pocket payments are useful in discouraging frivolous demand and limiting costs, they may restrict access to care in the case of catastrophic or chronic illness and for those unable to afford even modest co-payments on services covered by the NHI. At present, half of copayments exceeding 1.2 million won per month (60\% of the average wage) are covered and there is a cap of 3 million won in co-payments over a six-month period. Even co-payments of such an amount could block access for low-income persons or patients with chronic illness.

42. Nonetheless, further reductions in the co-payment rates should be avoided to limit the increase in public outlays. At the same time, the burden on employed persons should be eased by several reforms. First, elderly persons, who are currently exempted from contributions to the NHI if they have working children, should be required to contribute. Given the maturation of the public pension system, elderly persons will be in a better financial position to shoulder more of the burden. Second, as with the NPS, it is essential to more accurately assess the income of the self-employed and reduce underreporting in order to achieve an equitable sharing of the financial burden among the labour force. The government currently pays about half of the contributions for the self-employed, resulting in transfers from low-income employees to high-income self-employed persons. In sum, it is important to ensure the fiscal sustainability of the NHI, while trying to provide an appropriate level of healthcare services.

\section{Promoting efficiency and high-quality healthcare}

43. Less than half of Koreans are satisfied with their medical services according to a 2006 government survey. High medical fees, reflecting large out-of-pocket payments, and unsatisfactory treatment, perhaps due to limits on the cost of healthcare, were the major complaints (Table 10). In addition, $17.5 \%$ cited long waiting times and $6.6 \%$ cited over-treatment. Koreans have an average of 10.6 medical consultations per year, compared to an OECD average of 6.6. However, the number of doctors per 1000 population in Korea was 1.6 in 2004, the second lowest among OECD countries and well below the OECD average of 3.0. Similarly, the number of nurses per capita was only 1.8, compared to the OECD average of 8.3. This suggests a pattern of frequent but short visits, as doctors compensate for low fees by raising the volume of consultations in Korea's fee-for-service system. Given the large number of visits and the low number of doctors, the number of consultations per doctor is one of the highest in the OECD area, suggesting low quality. As the government does not restrict supply, the small number of doctors and nurses suggests that the attractiveness of medical careers is limited by low prices for such services. One option to increase medical personnel is to relax controls on the inflow of foreign workers, such as nurses (see the 2007 OECD Economic Survey of Korea).

17. Out-of-pocket payments include co-payments for services covered by the NHI as well as the costs of illness not covered by the NHI.

18. The government has recently extended the coverage of the NHI to include certain major diseases, additional diagnostic procedures, some "hotel" services and catastrophic cover. 
Figure 9. Projected increase in public spending on healthcare and long-term care Over the period 2005 to 2050, in per cent of GDP

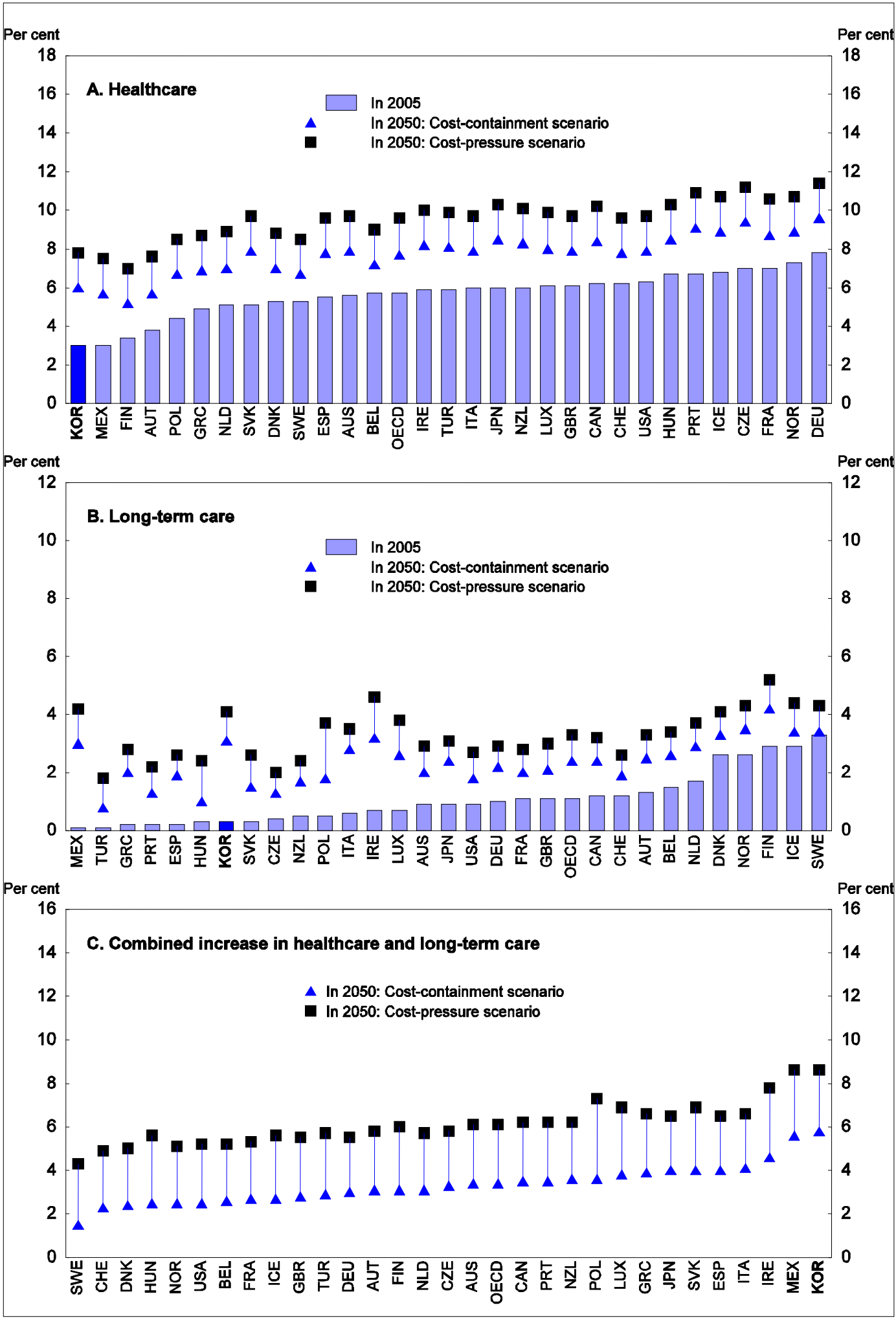

Source: OECD (2006d). 


\section{Box 4. Korea's healthcare system}

Korea has achieved universal coverage of health insurance in a relatively short time and at a relatively low cost. Healthcare is provided primarily by the private sector; about $90 \%$ of specialist doctors work in the private sector and $93 \%$ of medical institutions are privately-owned. ${ }^{1}$ Consumers are free to choose healthcare providers. Financing is divided between the public sector $(51 \%)$ and the private sector $(49 \%)$. Among public sources, the National Health Insurance (NHI) is most important, providing $41 \%$ of total health expenditure (Figure 10). The $\mathrm{NHI}$ is funded by employers, employees and the self-employed, with the government paying about half of the premiums for the latter group. The government accounts for an additional $10 \%$ of outlays, in part for the Medical Aid Programme, which provides care for the very poor. The key private-sector funding source for healthcare is out-of-pocket payments by patients, accounting for $37 \%$ of total outlays. The high share, which includes co-payments on services covered by the $\mathrm{NHI}$ and full payment for non-covered services, reflects the government's objective of achieving universal coverage of the $\mathrm{NHI}$ at low contribution rates by keeping benefits low and excluding some diseases and diagnostic procedures. The co-payment rate is $20 \%$ for hospital care and $30 \%$ to $50 \%$ for outpatient care. Consequently, the NHI provides relatively comprehensive but shallow protection in case of illness. The system may also pose barriers to access for the poor since co-payments are unrelated to income and the cap on total co-payments is rather high (see below). Private insurance accounts for only $4 \%$ of healthcare expenditures.

Figure 10. Evolution of Korean health expenditure by source of financing

Per cent of total

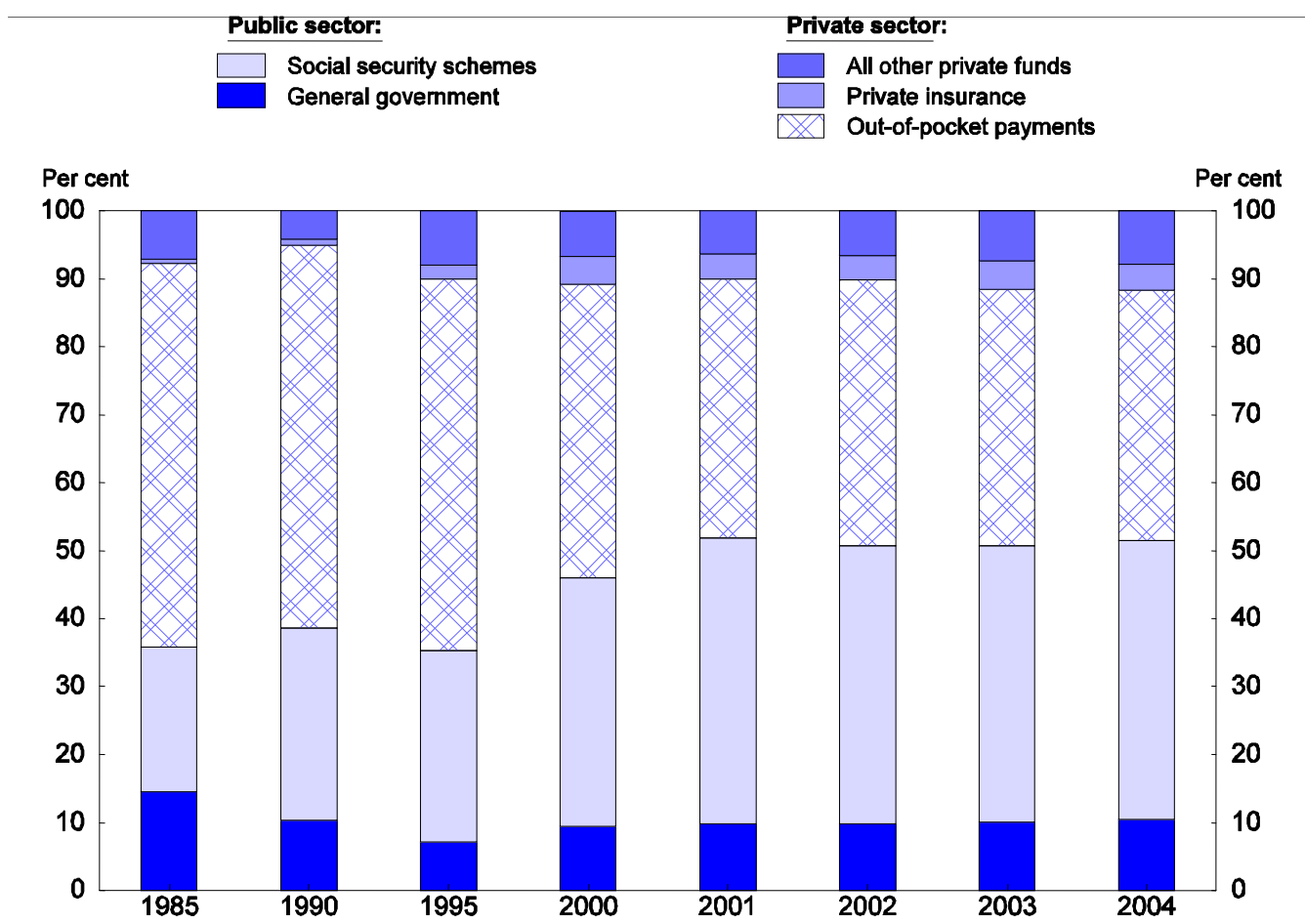

Source: OECD (2006), Health Database, OECD, Paris.

At present, medical fees are set through negotiations between the $\mathrm{NHI}$ and healthcare providers, and the prices of pharmaceuticals are set by the government. These prices determine the payments from the NHI to providers for their treatment of insured persons. All medical providers are under compulsory contract with the $\mathrm{NHI}$ and subject to the government fee schedule. The government has limited healthcare expenditures by constraining the rate of increase in medical fees. 
Until 2000, the NHI was fragmented, consisting of nearly 400 quasi-public insurance societies established to achieve universal coverage. Given the variety of methods of calculating contributions and benefits, individuals with similar income often paid different contribution rates for the same benefits, resulting in horizontal inequality. The 2000 Integration Reform combined the insurance societies into a single insurer and set a uniform contribution rate for all employees, thus improving equity. The reform also increased efficiency in management; administrative costs fell from $6.4 \%$ of total expenditures in 2000 to $3.7 \%$ in 2004 . In addition, the reform gave market power to the $\mathrm{NHI}$ as the sole purchaser of healthcare services. However, the reform has not resolved the problem of evasion or underpayment of contributions by the self-employed.

The Separation Reform of 2000 split the physician's role of prescribing and the pharmacist's role of dispensing drugs. The sale of drugs was important to doctors, accounting for between one-third and a half of their total revenues, depending on their specialisation. The decision of doctors to prescribe drugs was thus influenced by profit motives. The Reform was intended to reduce the over-use of pharmaceuticals and improve the efficiency of the drug industry. Doctors responded by staging a number of strikes, leading to a $41 \%$ hike in medical fees to compensate them. The Reform thus exacerbated the financial problems of the $\mathrm{NHI}$, resulting in a deficit of 2.2 trillion won (one-fifth of expenditures) in 2001. In addition to the sharp hike in medical fees, the Reform boosted expenditures by increasing the number of doctor visits to obtain prescriptions formerly handled by pharmacies and the use of more expensive drugs as doctors lost the incentive to prescribe discounted medicines. The government launched a programme in 2001 to bring the $\mathrm{NHI}$ back into surplus; $i$ ) government subsidies to the self-employed pool were raised to $50 \%$ of contributions; ii) income assessment for the self-employed was to be improved; iii) co-payments were raised; iv) detection of fraud by providers was to be improved; and $v$ ) the contribution rate was raised from $3.4 \%$ to $4.5 \%$ by 2006 . These reforms helped return the $\mathrm{NHI}$ to surplus in 2003.

1. The government maintains around 250 primary healthcare facilities in rural areas to fill gaps in private provision.

Table 10. Reasons for dissatisfaction with medical services in Korea Percentages in 2006

\begin{tabular}{lccr}
\hline & Whole country & Urban areas & Rural areas \\
\cline { 2 - 4 } High medical fees & 27.2 & 27.9 & 23.0 \\
Unsatisfactory treatment & 22.9 & 22.9 & 22.9 \\
Waiting time for treatment and hospitalisation & 17.5 & 17.7 & 16.4 \\
Unkindness & 11.1 & 11.0 & 11.8 \\
Inappropriate treatment & 9.2 & 9.3 & 8.9 \\
Over-treatment & 6.6 & 6.8 & 5.5 \\
Poor equipment & 2.7 & 2.2 & 6.4 \\
Others & 2.7 & 2.3 & 5.2 \\
Total & 100.0 & 100.0 & 100.0 \\
\hline
\end{tabular}

Source: Korea National Statistical Office (2006).

44. Allowing for-profit companies to provide healthcare and a greater role for private health insurance may help increase the satisfaction of consumers. At present, only "medical legal persons" are permitted to establish medical institutions, and they are limited to one institution each. Foreign providers of medical care are thus excluded, except in the three Free Economic Zones and Jeju Special Governing Province (see Jones and Yoon, 2008). The possibility of allowing a larger role for the private sector in medical care in the rest of the country is now under discussion. As for private insurance, it accounts for only $4 \%$ of healthcare spending (Figure 10) and half of this amount is accounted for by compulsory insurance against car accidents. Allowing private insurance to cover more healthcare services not reimbursed by the NHI would help meet consumer demand. However, the role of private insurance is limited by the government's concern that it will lead to a polarisation in healthcare provision. This should 
be accompanied by measures to ensure access to healthcare for low-income individuals and those facing catastrophic health expenditures.

\section{Limiting the cost of healthcare}

45. Although the contribution rate for the NHI has risen from $3.4 \%$ in 2001 to $4.8 \%$ in 2007 , it remains well below the level of other OECD countries such as Japan (8.5\%), Germany (14\%) and France (18.5\% to 20\%). Ideally, expenditure plans should be linked to forecasts of revenues, based on a tax burden acceptable to taxpayers. Cost containment thus far has relied primarily on controlling fees. However, since the strikes by doctors in the wake of the Separation Reform in 2000 (see Box 4), fees are now decided by collective bargaining rather than by government fiat. Cost control measures should focus on factors that put expenditures on an unsustainable growth path in the long run. Despite the hike in contribution rates and in government support (from 3.1 trillion won in 2002 to 3.9 trillion won - 0.5\% of GDP - in 2006), the NHI returned to deficit in 2006 in the wake of a one-third increase in spending between 2004 and 2006.

46. One problem is that the fee-for-service reimbursement system tends to boost outlays as doctors increase the number of appointments. Incentives for the efficient use of resources would be improved by the introduction of other payment systems, such as: 1) resource-based relative value scale, in which payments are based on the level of resources needed to provide each service; 2) volume-related reimbursement, which reduces the unit fee for incremental treatments so that providers have less incentive to increase volumes; and 3) Diagnostic Related Groups, in which reimbursement for a specific diagnosis is rate-based (Docteur and Oxley, 2003). Finally, the Integration Reform (see Box 4) should allow the NHI to become a more active and effective purchaser of health services for its clients rather than passively paying for all claims. Strengthened auditing and assessment of medical bills will help to reduce costs.

47. The projection of future healthcare spending in Korea shown in Figure 9 assumes that further increases in life expectancy are matched by a corresponding rise in the average healthy lifespan. If extended longevity were instead accompanied by longer periods of disability, healthcare spending would rise even faster than projected. On the other hand, reducing the length of disability would slow the rise in healthcare expenditures. The Korean authorities recognised this link in the Health Plan 2010, which set a target of a "healthy life span" of 72 years. The plan includes 108 objectives in 24 areas. One key is to further reduce the rate of smoking among men, which was the highest in the OECD area at almost 60\% in 2004. Increases in cigarette prices, the expansion of smoke-free areas and the implementation of smoking prevention programmes helped to lower the proportion to 50\% in 2005, with an objective of 30\% by 2010 . A second priority is to maintain healthy diets. Total calorie consumption is among the lowest in the OECD area, keeping the proportion of obesity at 30\%, the second lowest in the OECD area. Nevertheless, the rate of obesity is increasing rapidly in Korea and is about $60 \%$ higher than a decade ago. Illness prevention and health promotion policies are needed to slow the increase in demand for healthcare as the population ages.

48. The 2000 Separation Reform, which removed doctors from the profitable business of dispensing pharmaceuticals to their patients, has not achieved its objective of reducing the use of pharmaceuticals. Indeed, its share of healthcare spending has declined only slightly, from $27.8 \%$ in 2000 to $27.4 \%$ in 2004 , which is well above the OECD average of $17.7 \%$. However, given the lower level of healthcare spending in Korea, spending on pharmaceuticals is close to the OECD average of 1.6\% of GDP. Nevertheless, a new framework to encourage cost-effective use of pharmaceuticals based on audits and appraisal of doctors' prescription behaviour, the introduction of prescription guidelines and greater use of generic drugs may result in savings in the use of pharmaceuticals in Korea. ${ }^{19}$

19. In May 2006, the government announced the Drug Expenditure Rationalisation Plan, which aims at guaranteeing affordable access to cost-effective pharmaceuticals, as well as to rationalise national drug expenditures. The new Plan was implemented in December 2006. 
49. The average length of stay in hospitals for acute care was 10.6 days in Korea in 2004, compared to an OECD average of seven days. One reason is the growing pressure on hospitals to care for elderly people who need long-term care. Indeed, at least $14 \%$ of inpatient cases in acute care hospitals are inappropriate (Kwon, 2006). The pressure to provide long-term care is one factor driving the rapid growth in the number of acute care hospital beds from 3.6 per 1000 in 1994 to 5.9 in 2003, compared to an OECD average of 4.1. "Social admissions" to hospitals is an expensive method to assist elderly persons who need nursing care. The further development of long-term care facilities, which would reduce the pressure on the healthcare system, is discussed in the following section.

\section{Providing long-term care for the elderly}

50. Public expenditures on long-term care amounted to 0.3\% of GDP in 2005, well below the OECD average of $1.1 \%$ (Figure 9, Panel B). The government's role is focused on providing in-home or institutional care to persons qualifying for social assistance. The low overall level of spending on longterm care reflects Korea's relatively young population at present and the heavy reliance on informal family care provided primarily by daughters (49\%) and spouses (32\%). Indeed, the concept of formal long-term care is new in Korea. Only $0.4 \%$ of the elderly in 2004 received long-term care in institutions, the lowest among the 23 OECD countries for which data are available and well below the average of $4.5 \%$ (Table 11).

Table 11. International comparison of long-term care

\begin{tabular}{|c|c|c|c|c|c|c|}
\hline & \multicolumn{3}{|c|}{ Number of recipients (\% of elderly) ${ }^{1}$} & \multicolumn{3}{|c|}{ Expenditure on long-term care (\% of GDP) } \\
\hline & Institutions & In-home & Total & Public & Private & Total \\
\hline Korea & 0.4 & 0.7 & 1.1 & 0.2 & 0.1 & 0.3 \\
\hline Italy & 1.5 & & & & & \\
\hline Ireland & 1.8 & & & 0.5 & 0.1 & 0.6 \\
\hline Germany & 2.4 & 6.1 & 8.5 & 1.0 & 0.4 & 1.4 \\
\hline Japan & 3.0 & 9.3 & 12.3 & 0.8 & 0.1 & 0.8 \\
\hline United States & 3.6 & & & 0.7 & 0.5 & 1.3 \\
\hline Austria & 3.6 & 19.3 & 22.9 & 1.3 & & \\
\hline Luxembourg & 3.9 & 4.5 & 8.4 & 0.5 & & \\
\hline Canada & 4.2 & & & 1.0 & 0.2 & 1.2 \\
\hline United Kingdom & 4.2 & 6.9 & 11.1 & 0.9 & 0.5 & 1.4 \\
\hline Denmark & 4.4 & 21.5 & 25.9 & & & \\
\hline New Zealand & 4.5 & 9.0 & 13.5 & 0.5 & 0.2 & 0.7 \\
\hline Czech republic & 4.9 & 8.2 & 13.1 & & & \\
\hline Finland & 4.9 & 6.9 & 11.8 & & & \\
\hline Slovak Republic & 5.1 & & & & & \\
\hline Australia & 5.3 & 6.2 & 11.5 & 0.9 & 0.3 & 1.2 \\
\hline Netherlands & 5.6 & & & 1.3 & 0.1 & 1.4 \\
\hline Norway & 5.8 & 17.4 & 23.2 & 1.9 & 0.3 & 2.2 \\
\hline France & 6.3 & 5.2 & 11.5 & & & \\
\hline Belgium & 6.6 & 7.5 & 14.1 & & & \\
\hline Switzerland & 6.6 & 9.4 & 16.0 & & & 1.5 \\
\hline Sweden & 7.5 & 9.5 & 17.0 & 2.7 & 0.1 & 2.9 \\
\hline Hungary & 8.0 & 15.1 & 23.1 & 0.2 & 0.1 & 0.3 \\
\hline Average $^{2}$ & 4.5 & 9.6 & 13.8 & 1.0 & 0.2 & 1.2 \\
\hline
\end{tabular}

1. Countries ranked by percentage of elderly receiving long-term care in institutions.

2. The average for the total number of recipients includes only the countries for which both institutional and in-home care is available and the average for total expenditure includes only those countries for which both public and private expenditures are available.

Source: DELSA dataset. 
Similarly, the proportion receiving formal paid care at home is only $0.7 \%$, well below the OECD average of $9.6 \%$. With long-term care facilities available for only $0.4 \%$ of the elderly at present, the growing need for long-term care is met by acute care hospitals, placing an increasing strain on the NHI.

51. Demographic trends will increase spending on long-term care, which grows exponentially with age, with the bulk concentrated on persons over the age of 80 . In Korea, the number of persons above that age is projected to increase nine-fold by mid-century, rising from $1 \%$ of the population at present to $14 \%$. In addition, growing female participation in the labour force and the falling proportion of elderly living with their family will reduce the scope for family-based care, creating the need for a better developed social infrastructure for providing care. The OECD estimates that public spending on long-term care will rise to between $3 \%$ and $4 \%$ of GDP by 2050 , above the OECD average of $2.4 \%$ to $3.3 \%$ (Figure 9). As is the case for healthcare, the projected increase is among the largest in the OECD area.

52. The challenge is to provide wider and more equitable access to long-term care services within the constraints of fiscal sustainability. The public sector in Korea provides institutional long-term care to about 15000 persons, about $90 \%$ of the elderly in institutions at present. Of the 679 long-term care facilities in August 2006, 77\% were public facilities, with private institutions focused on the upper end of the market. The authorities plan to add 1112 public long-term care facilities, with 30000 additional places, between 2006 and 2008, with another 6000 places provided by the private sector. The government will encourage a larger private-sector role after it further develops public long-term care.

53. As in the case of childcare, providing vouchers to households would increase consumer choice in long-term care and improve the satisfaction of older persons and increase their degree of independence (Lundsgaard, 2005). Shifting Korea's current approach of relying on the government to provide most longterm care facilities would foster competition among providers and more choice for families, while limiting government outlays (OECD, 2005a). Concerns about quality can be met by requiring that support for the elderly be used for long-term care provided by licensed facilities.

54. A national long-term care insurance system is to be introduced in 2008, an approach currently used in Germany, Japan, Luxembourg and the Netherlands, while Austria finances long-term care from the general budget and gives individuals more freedom in choosing their care (Lundsgaard, 2005). Contributions are to be collected by the NHI, with an initial rate expected to be set at around $0.25 \%$ of employee income. ${ }^{20}$ Beneficiaries, who will be chosen by the Health Insurance Corporation from among the elderly suffering geriatric diseases, can receive public care at home or in institutions, or cash benefits to pay for private care. The number of beneficiaries is to be initially limited to 80 thousand $(1.7 \%$ of the elderly population). However, 350 thousand elderly persons ( $8.3 \%$ of the elderly) were already suffering from dementia in 2005 . The number of beneficiaries is expected to double by 2010 . Recipients of care pay $20 \%$ of the cost of home and institutional care, ${ }^{21}$ with insurance contributions covering $50 \%$ and the government $30 \%$. In implementing this new insurance system, it is important to learn from the experience of other countries (Box 5).

20. For the self-employed, the contribution will be set at $5.5 \%$ of the NHI premium. As in the case of pensions and healthcare, the lack of transparency about the income of self-employed is a serious problem.

21. There is a reduction for low-income elderly and those eligible for social assistance will pay nothing. 
ECO/WKP(2008)23

\section{Box 5. Long-term care insurance: lessons from Japan}

In response to the rising number of elderly people and increasing medical costs, Japan launched the Long-Term Care Insurance System (LTCl) for the elderly in April 2000 as a third pillar of social security along with pensions and healthcare. This mandatory insurance is operated by municipalities and provides benefits to persons over the age of 65 who are certified as eligible based on an objective assessment of their physical and mental condition by the municipality in which they live. Neither the willingness and/or ability of family and friends to provide care are taken into account in deciding eligibility. Once eligibility is determined, a "care manager" employed by the municipality develops an appropriate plan of care. The system allows consumer choice of services and providers, and includes institution and home-based care. The fees for LTCl services are set by the government and apply to all providers, which are subject to quality standards that are set nationally. Patients are required to pay $10 \%$ of the cost, with the remainder split equally between the government ${ }^{1}$ and insurance contributions. Contributions are set by municipalities at levels sufficient to cover their costs. On average, persons over the age of 65 paid 4090 yen (\$35) per month in FY 2006, while those in the 41 to 64 age range paid a similar amount, with the premium spilt between employer and employee.

There has been a remarkable expansion of long-term care utilisation in Japan since 2000 resulting from the release of pent-up demand (Shimizutani, 2006). The number of beneficiaries more than doubled between 2000 and 2005 , while expenditures rose from $0.7 \%$ to $1.3 \%$ of GDP (Figure 11 ), well above the projected level. This is due in part to a "remarkable" increase in the number of elderly receiving low levels of care. ${ }^{2}$ To contain costs, the government launched a major revision of the LTCI in April 2006 that restricted the provision of home-care for those with mild disabilities and introduced preventative measures aimed at cutting demand for long-term care. In addition, it hopes to reduce the use of institutional care by lowering the generosity of coverage relative to home care. Under the original system, it was cheaper in some cases to check into a facility even if only a low level of care were needed. As a result, the number of beneficiaries receiving institution-based care rose by $50 \%$ between 2000 and 2005. Meanwhile, the proportion receiving homecare increased by $159 \%$.

The experience of Japan has useful lessons for Korea:

- The release of pent-up demand following the introduction of LTCI spurred a $131 \%$ increase in the number of private providers of long-term care, from around 20000 in 2000 to more than 50000 in 2005 (Shimizutani, 2006). It is thus essential to eliminate any regulations that may discourage the entry of new companies.

- It is important to avoid a supply-driven increase in the number of elderly receiving relatively low levels of care. The sharp increase in Japan reflects in part the tendency of care managers to err on the side of generosity in approving care. Moreover, some may have been effectively captured by service providers, illustrating the importance of ensuring the neutrality of care managers (Imai and Oxley, 2005). In contrast, in the case of Australia, care managers have been effective in their role as gatekeepers (OECD, 2005a).

- It is important to stabilise or even reduce the number of persons cared for in institutions. In a number of countries, including the United States, there has been an absolute decline in the number of elderly cared for in institutions, reflecting an increase in the types of homecare available (OECD, 2005a).

- $\quad$ There is a wide variation in premium payments, with the elderly in more sparsely populated areas paying two-thirds more than the national average (Saidel, 2004). Even with additional payments from the central government, the number of long-term care users in such areas has exceeded the ability of municipalities to pay, forcing higher premiums. 


\section{Figure 11. Expansion of Long-term Care Insurance in Japan}

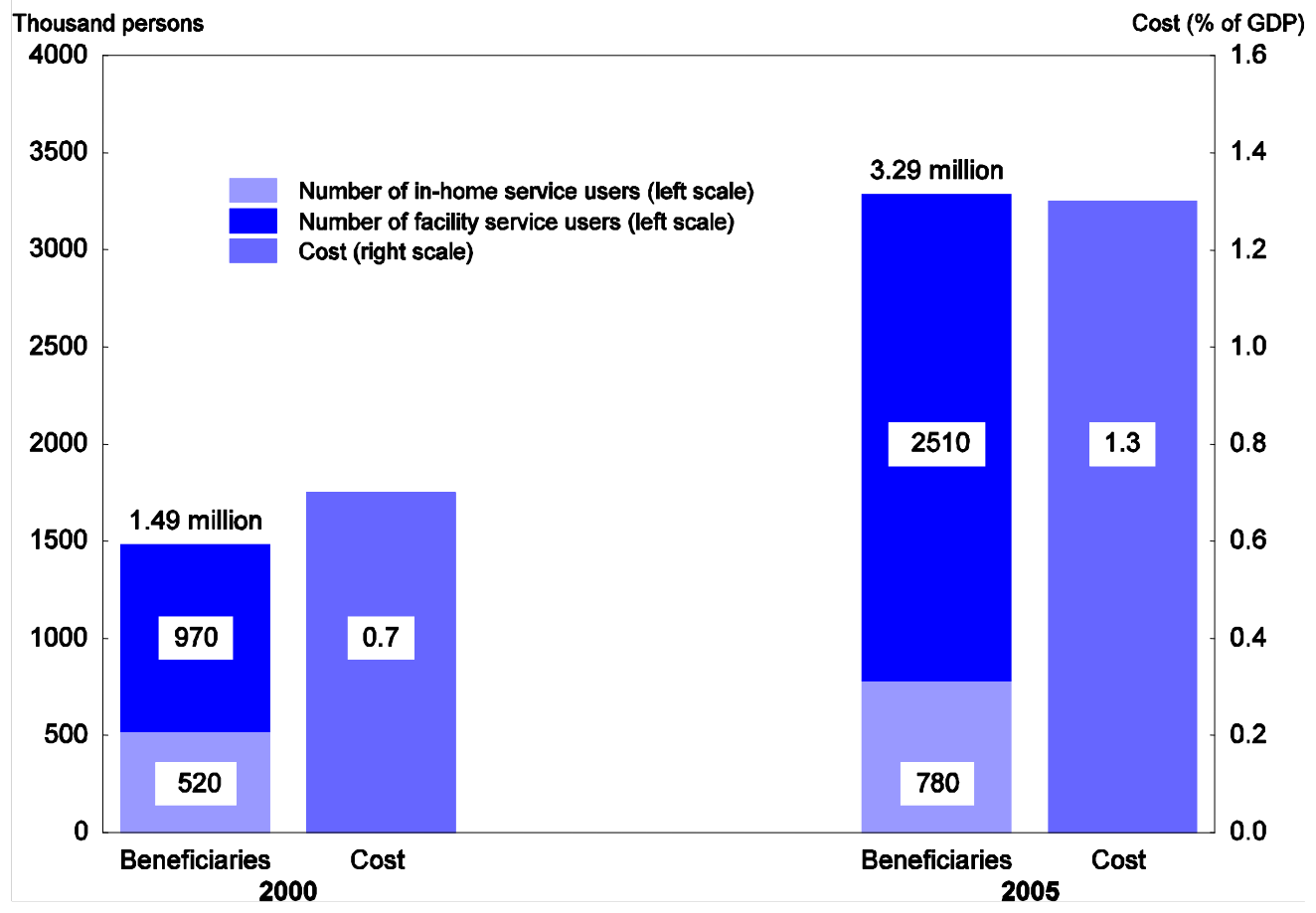

Source: Ministry of Health, Labour and Welfare (2006).

1. The central government pays $25 \%$, while prefectural and local governments pay $12.5 \%$ each.

2. Ministry of Health, Labour and Welfare (2006). Elderly requiring "Care Level 1" account for half of beneficiaries.

\section{Social assistance in the context of rising relative poverty and income inequality}

55. Most social assistance to families is provided through the National Basic Livelihood Security System (NBLSS). This system, which was formerly called the Livelihood Protection Programme, has been strengthened and enlarged since the financial crisis. It provides cash benefits for living, housing and education, as well as medical care, in order to ensure that all households have an income at least equivalent to the national minimum cost of living. The minimum level was increased by $7 \%$ in real terms between 1999 and 2005, reaching 0.4 million won per month for an individual (20\% of the average wage). Meanwhile, the number of recipients has risen from $1.2 \%$ of the population to around $3 \%$.

56. While the NBLSS has been improved, there remain several concerns. First, in addition to an income test, eligibility depends on asset and family criteria. Combined income and assets must be less than the minimum cost of living, while only persons without relatives capable of supporting them are eligible for assistance. According to one estimate, only about half of the persons with income below the minimum cost receive assistance (Park, 2005). Second, the lack of transparency about income of the self-employed may divert benefits to those who are not eligible. Third, the NBLSS discourages work as there is no earnings disregard.

57. In most OECD countries, social spending and tax systems significantly reduce relative poverty, defined as an income of less than half of the national median. Indeed, social spending and taxes reduced 
the poverty rate by more than half, from an average of $18.2 \%$ to $8.4 \%$ in the OECD area in $2000 .^{22}$ The combined effect of government spending and tax measures have only a modest impact on the level of poverty in Korea, compared to other OECD countries (Park et al., 2002), reflecting the still low level of social spending in Korea (Table 1). However, the effectiveness of social spending on reducing poverty also depends on its composition and targeting of spending. ${ }^{23}$ In Korea, $74 \%$ of public social outlays is spent on health and pensions, and is thus concentrated on the elderly. In contrast, only $10 \%$ is spent on the workingage population, considerably below the OECD average of $17 \% .{ }^{24}$ In particular, family benefits amount to only $0.1 \%$ of GDP in Korea compared to an OECD average of $2.2 \%$.

\section{Relative poverty}

58. The limited impact of social assistance on relative poverty, which has risen since the 1997 crisis, is a concern. Indeed, the rate of relative poverty increased from $8.7 \%$ in the mid-1990s to $13 \%$ in $2000-$ from below the OECD average to considerably above it (Figure 12). Furthermore, the upward trend continued, though at a slower pace, to $15.5 \%$ in 2003 . As in other OECD countries, population ageing and changes in household structure - more single-person and female-headed households - have played a role in boosting poverty (Table 6). However, increased poverty among families headed by a couple accounted for most of the rise in poverty, suggesting that higher income inequality was the key factor. ${ }^{25}$

59. The government plans to introduce in 2008 an Earned Income Tax Credit (EITC) similar to that in the United States, in part to strengthen work incentives. The programme will be introduced on a limited scale to salaried workers with two or more children, who do not own a home and have assets of less than 100 million won (about $\$ 110000$ ). The income ceiling (gross annual basis per household) is 17 million won ( $70 \%$ of the average wage), about $20 \%$ higher than the minimum cost of living for a family of four. The EITC will provide $10 \%$ of earnings up to an annual income of 8 million won, with a ceiling of 0.8 million won. The tax credit will be phased out from 12 million won. The EITC is to be gradually extended to the self-employed over the coming decade. However, the problem of accurately determining the income of the self-employed makes the EITC inappropriate for the entire population.

22. An average of 17 OECD countries for which data are available. See Förster and Mira d'Ercole, 2005.

23. For example, tax and benefit policies reduce relative poverty by $57 \%$ and $73 \%$ respectively in Italy and the Netherlands, even though gross public social spending is higher in Italy (24.1\% of GDP) than in the Netherlands (20.7\%). See Förster and Mira d'Ercole, 2005.

24. The relatively high level of mandatory private social spending (Table 1) is concentrated on employees of large companies, who are the highest paid employees in Korea. Consequently, private social spending by firms is not likely to have much impact on income redistribution and may even increase inequality.

25. The relative poverty rate, measured by a threshold of $40 \%$ of the median income, rose from $4.6 \%$ in 1996 to $8.1 \%$ in 2000 . Increased poverty among households including married couples $-83 \%$ of all households - accounted for more than 2 percentage points of the increase. See Ku, 2004. 
Figure 12. International comparison of relative poverty rates

The entire population in $2000^{1}$

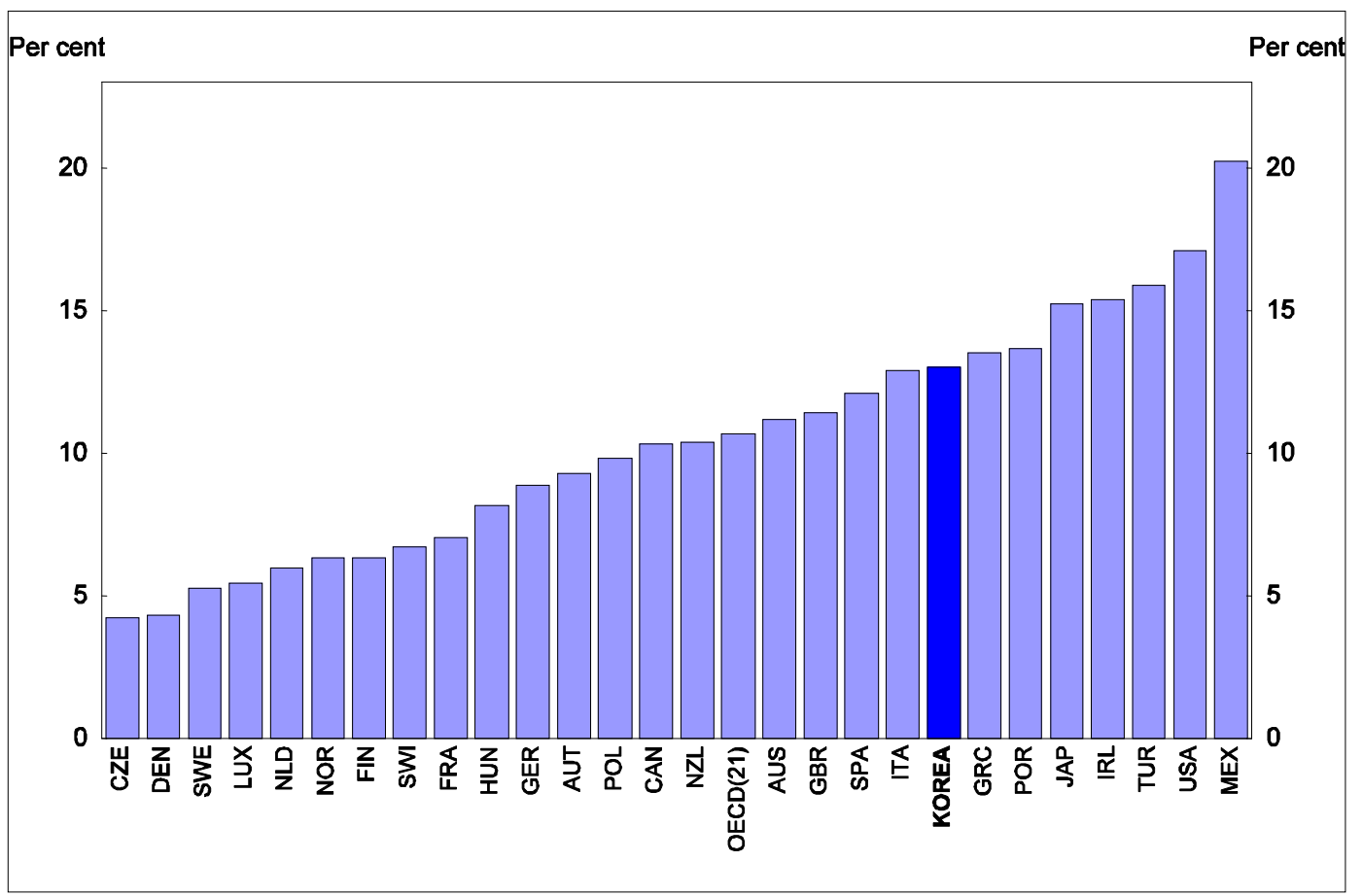

1. Poverty rates are defined as the share of individuals with equalized disposable income less than $50 \%$ of the median for the entire population.

Source: Förster and Mira d'Ercole (2005) and Yeo et al. (2005).

\section{Rising income inequality and the labour market}

60. Rising poverty was accompanied by higher income inequality, ${ }^{26}$ which increased according to a number of measures (Table 12). For example, the ratio of the top income decile to the bottom has risen from 7.4 in 1990 to 9.3 in 2004 . The decline in inequality recorded during the rapid growth in the first half of the 1990s was reversed by the 1997 crisis and the severe recession in 1998. Since then, measures of inequality have fluctuated around the higher level, falling during the years of strong growth (2000-02) and rising following the collapse of the household credit bubble and relatively weak growth since then. The Gini coefficient on a nation-wide basis was 35.1 in 2006, the sixth highest in the OECD area and $13 \%$ above the OECD average (Figure 13). The high level of inequality reflects the relatively low level of social spending, resulting in little scope for redistribution, and a high degree of wage dispersion. For full-time workers, the ratio of the 90th to 10th earning percentiles is 4.0, well above the OECD average.

26. Patterns in inequality and relative poverty over time are similar in most OECD countries. The correlation of the Gini coefficient and the relative poverty rate during the period 1970 to 2001 was 0.90 . 
Table 12. Indicators of income inequality in Korea For urban salary and wage-earner households ${ }^{1}$

\begin{tabular}{lccc}
\hline & Gini coefficient $^{2}$ & Quintile ratio $^{3}$ & Decile ratio $^{4}$ \\
\cline { 2 - 4 } 1990 & 29.5 & 4.6 & 7.4 \\
1991 & 28.7 & 4.5 & 7.0 \\
1992 & 28.4 & 4.4 & 7.0 \\
1993 & 28.1 & 4.4 & 6.8 \\
1994 & 28.4 & 4.4 & 6.9 \\
1995 & 28.4 & 4.4 & 6.8 \\
1996 & 29.1 & 4.6 & 7.2 \\
1997 & 28.3 & 4.5 & 7.0 \\
1998 & 31.6 & 5.4 & 9.4 \\
1999 & 32.0 & 5.5 & 9.3 \\
2000 & 31.7 & 5.3 & 8.8 \\
2001 & 31.9 & 5.4 & 8.8 \\
2002 & 31.2 & 5.2 & 8.3 \\
2003 & $30.6(34.1)$ & $5.2(7.2)$ & $8.9(15.5)$ \\
2004 & $31.0(34.4)$ & $5.4(7.4)$ & $9.3(15.7)$ \\
2005 & $31.0(34.8)$ & $5.4(7.6)$ & $9.1(15.9)$ \\
2006 & $31.0(35.1)$ & $5.4(7.6)$ & $9.1(15.9)$ \\
\hline
\end{tabular}

1. Nation-wide data, available since 2003, is shown in parentheses.

2. The Gini coefficient is defined as the area between the Lorenz curve (which plots cumulative shares of the population, from richest to poorest, against the cumulative share of income that they receive) and the 45-degree line, taken as a ratio of the whole triangle. The values, which range from 0 in the case of perfect equality and 1 in the case of perfect inequality, are multiplied by 100 to give a range of 0 to 100 .

3. The ratio of the top quintile to the bottom quintile.

4. The ratio of the top decile to the bottom decile.

Source: Korea National Statistical Office.

Figure 13. International comparison of income inequality Gini coefficient * $100^{1}$

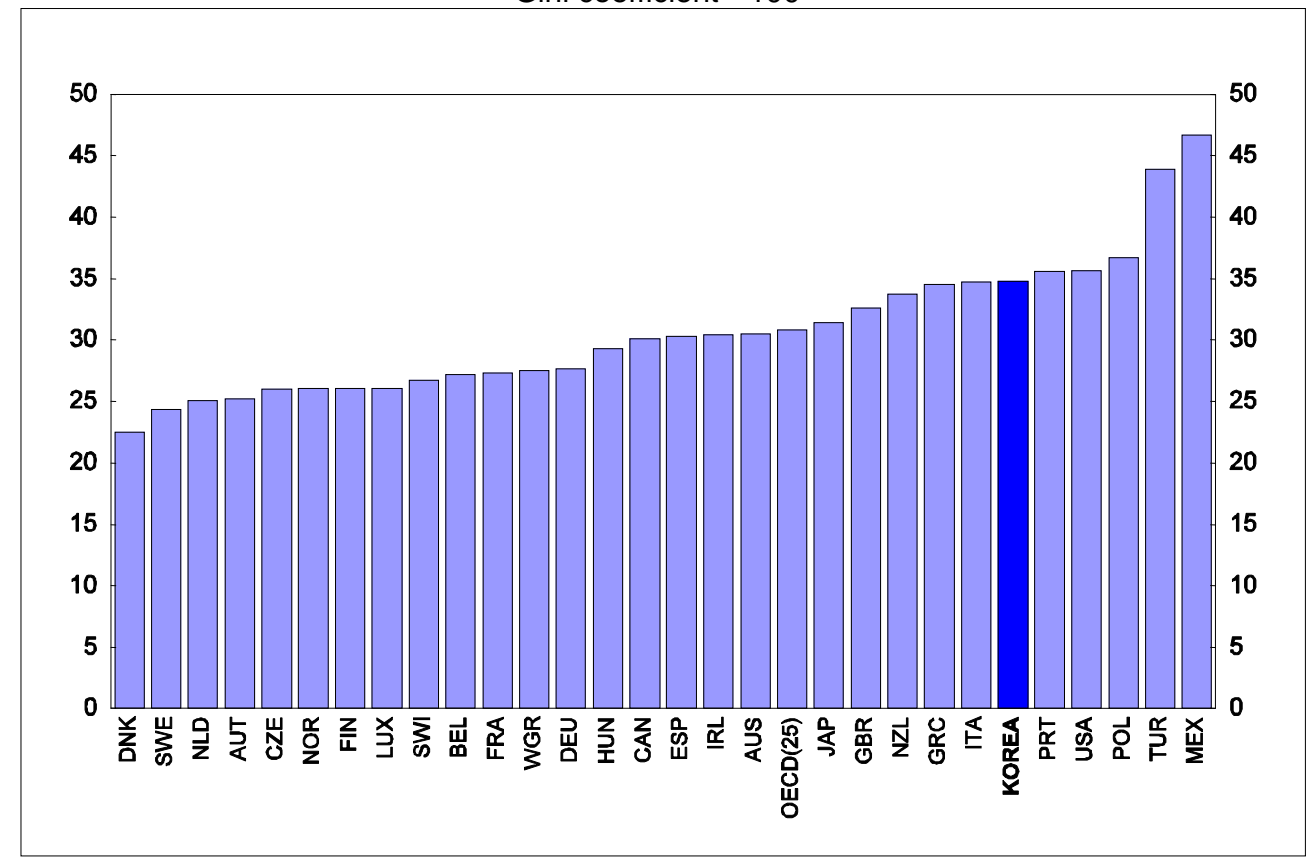

1. See Table 12 for a definition of the Gini coefficient.

Source: Förster and Mira d'Ercole (2005) and the Korea National Statistical Office. 
61. The rising level of inequality is explained in part by the increasing share of temporary workers from $16.6 \%$ in 2001 to $29.4 \%$ in 2005 (Table 13 ), ${ }^{27}$ the second highest in the OECD area. Workers on fixed-term contracts of one year or less, account for more than half of temporary workers. There is a large wage gap: non-regular workers (as defined by the Korea supplementary labour force survey) earned 62\% as much as regular workers in 2005. A second factor explaining the upward trend in inequality is the increasing wage gap between large and small firms. The average wage at SMEs has fallen from $71 \%$ of that in large firms in 2000 to $64 \%$ in 2005 , reflecting the difficulties facing smaller firms in the context of exchange rate appreciation and weak private consumption. The widening gap is also due in part to greater use of non-regular workers in smaller firms. In 2005, non-regular workers accounted for $54 \%$ of employees in small firms compared to $18 \%$ in large firms. Moreover, the wage gap is larger in SMEs: non-regular workers in small firms earn only half as much as regular workers, while those in large firms earn two-thirds.

Table 13. Share of temporary workers in Korea Per cent of employees ${ }^{1}$

\begin{tabular}{|c|c|c|c|c|c|c|}
\hline & & 2001 & 2002 & 2003 & 2004 & 2005 \\
\hline $\begin{array}{l}\text { Workers } \\
\text { with a } \\
\text { fixed-term } \\
\text { contract }\end{array}$ & $\begin{array}{l}\text { Less than or equal to } 1 \text { month } \\
\text { More than } 1 \text { month to less than } 1 \text { year } \\
\text { Exactly one year } \\
\text { More than } 1 \text { year to less than } 3 \text { years } \\
3 \text { years or more } \\
\text { Subtotal }\end{array}$ & $\begin{array}{r}5.6 \\
2.8 \\
1.5 \\
0.6 \\
0.5 \\
11.0\end{array}$ & $\begin{array}{r}5.2 \\
2.7 \\
1.9 \\
0.6 \\
0.6 \\
10.9\end{array}$ & $\begin{array}{r}6.7 \\
4.9 \\
3.3 \\
1.3 \\
0.7 \\
17.0\end{array}$ & $\begin{array}{r}5.6 \\
4.7 \\
4.4 \\
1.7 \\
0.8 \\
17.1\end{array}$ & $\begin{array}{r}5.5 \\
4.8 \\
5.3 \\
1.8 \\
0.8 \\
18.2\end{array}$ \\
\hline \multicolumn{2}{|c|}{$\begin{array}{l}\text { Workers without fixed-term contract, whose job is } \\
\text { not expected to continue due to involuntary reasons }\end{array}$} & 2.9 & 3.8 & 4.3 & 7.6 & 5.9 \\
\hline \multicolumn{2}{|c|}{ Temporary agency workers } & 1.0 & 0.7 & 0.7 & 0.8 & 0.8 \\
\hline \multicolumn{2}{|c|}{ On-call workers } & 2.2 & 2.9 & 4.2 & 4.6 & 4.8 \\
\hline \multicolumn{2}{|c|}{ Total $^{2}$} & \multicolumn{5}{|c|}{ Memorandum item: } \\
\hline \multicolumn{2}{|c|}{ Total dependent employment (thousands) } & 13540 & 14030 & 14149 & 14584 & 14968 \\
\hline
\end{tabular}

1. This table shows the share of employees who are temporary according to the OECD definition. The concept of non-regular worker in Korea includes other categories, such as part-time workers, and is higher at around $40 \%$.

2. The total is adjusted for overlapping categories. The Supplementary Survey has been carried out each August since 2001. There have been a few changes that may influence recent results. First, the sample of the monthly Economically Active Population Survey was replaced starting from January 2003 and the question on fixed-term contracts was moved to this Survey. Second, workers who assess the durability of their employment as unlimited because their contract is renewed on a regular basis are included in the "temporary" category since 2002.

Source: Ministry of Labour, Economically Active Population Survey and the Supplementary Survey of Economically Active Population Survey.

62. According to a survey of firms employing non-regular workers, $32.1 \%$ cited lower labour costs as the major reason for hiring such workers (Table 14). The lower wages are explained in part by productivity differences, though discrimination also plays a role. According to the Korea Employers Federation (2006), the productivity of non-regular workers is $22 \%$ below regular workers, while their wages are $44 \%$ less. Only one-half of the wage differential, therefore, is justified by productivity differences. Another study found that non-regular workers are paid $20 \%$ to $27 \%$ less than regular workers, after adjusting for age, experience, education and other attributes (Jeong, 2003). A more recent analysis reported that $23 \%$ of the

27. This figure refers to the share of workers who are temporary according to the OECD definition. In Korean statistics, the proportion of non-regular workers, which also includes other types of workers such as parttimers, in addition to temporary workers, is around $40 \%$. 
Table 14. Reasons for hiring non-regular workers Percentages

\begin{tabular}{lccccc}
\hline & Labour costs & Flexibility & Peripheral tasks & Short-term tasks & Others \\
\cline { 2 - 5 } & 32.1 & 30.3 & 18.5 & 13.9 & 5.2 \\
All industries & 28.7 & 34.5 & 17.9 & 14.7 & 4.1 \\
$\quad$ Manufacturing & 35.4 & 26.1 & 19.1 & 13.2 & 6.2 \\
$\quad$ Non-manufacturing & & & & 13.2 & 6.6 \\
Firms with & 35.5 & 28.9 & 15.8 & 18.2 & 7.0 \\
$\quad$ Less than 30 workers & 28.5 & 27.6 & 18.7 & 14.3 & 6.3 \\
30-99 workers & 37.7 & 26.2 & 15.5 & 12.7 & 3.9 \\
100-299 workers & 34.3 & 29.4 & 19.6 & 9.6 & 1.6 \\
300-499 workers & 26.1 & 39.9 & 22.9 & & \\
500 workers and more & & & & & \\
\hline
\end{tabular}

Source: Cited from Ahn et al. (2003).

wage gap is explained by discrimination. ${ }^{28}$ In addition to lower wages, non-regular workers also receive fewer benefits (Table 15). While $73 \%$ of regular workers receive the retirement allowance, over-time payments, regular bonuses and paid-holiday leave, $74 \%$ of non-regular workers receive none of these benefits. Labour costs are further widened by differences in social insurance coverage. More than fourfifths of regular workers are covered by all social insurance programmes - national pension, health and employment insurance - while two-thirds of non-regular workers have no work-based social insurance. The low coverage of non-regular workers is not primarily due to differences mandated by the law, but instead reflects weak compliance.

Table 15. The coverage of social insurance and benefits by type of employment

\begin{tabular}{lcr}
\hline & Regular employees & Non-regular employees $^{1}$ \\
\cline { 2 - 3 } Benefits $^{2}$ & & 9.5 \\
All & 73.0 & 16.3 \\
Some & 25.9 & 74.2 \\
$\quad$ Nothing & 1.1 & 29.4 \\
Social insurance & & 5.3 \\
All & 81.2 & 65.3 \\
Some & 17.4 & \\
Nothing & 1.4 & \\
\hline
\end{tabular}

1. In the paper by Ahn, non-regular workers includes temporary and daily workers, as well as "non-standard workers". The latter category includes workers on fixed-term and part-time contracts, as well as alternative employment (dispatched workers, temporary agency workers, independent contractors, on-call workers and home-based workers).

2. Includes the retirement allowance, over-time payments, regular bonuses and paid-holiday leave.

3. Includes the National Pension Scheme, National Health Insurance and the Employment Insurance System.

Source: Ahn (2006).

28. Ahn (2006). Thus, 9 percentage points of the 38-point gap between regular and non-regular workers is due to discrimination. The rest of the wage gap is explained by a workers' tenure $(20 \%)$, the industry in which they work (17\%), firm size (12\%), education level (11\%), gender and marital status (9\%), age (5\%) and occupation (4\%). Some of these factors may also be related to discrimination. 
63. The survey of employers also reported that $30 \%$ hire non-regular workers to increase employment flexibility, a rationale that was more important for large firms than for small firms, which focus more on reducing labour costs (Table 14). It is very difficult to lay off regular workers because of the Labour Standards $\mathrm{Act}^{29}$ and the power of trade unions. The OECD ranks employment protection for regular workers in Korea in the top third of member countries. In a world of increasing competition, Korean firms have an incentive to maintain a minimum number of regular workers and to adjust to demand fluctuations by hiring non-regular workers and outsourcing. Non-regular employment thus helps firms achieve the optimal level of employment, leading to profit maximisation. Countries with stricter protection for regular workers tend to have a higher incidence of temporary employment (Grubb et al., 2007).

64. According to a 2005 government survey, $80 \%$ of regular workers were satisfied with their employment, compared to only $29 \%$ of non-regular workers. However, $41 \%$ accepted non-regular employment because nothing better was available, while another $11 \%$ preferred non-regular employment as it provided working-time flexibility. Surprisingly, only $8 \%$ of non-regular workers hoped to use their current post as a stepping stone to another job, reflecting limited mobility between regular and non-regular employment. Of those who were non-regular workers in 2003, only $15 \%$ moved to regular employment during the following year, while 59\% remained in non-regular status. Moreover, 20\% lost their jobs and became unemployed or left the labour force, while 5\% became self-employed. It is clear that a considerable portion of non-regular workers are trapped in this type of employment. In contrast, less than $10 \%$ of regular workers moved to the categories of unemployment, inactivity or unpaid family workers.

65. In sum, non-regular employment is characterised by precarious jobs that pay low wages and provide limited coverage by the social safety net. The social polarisation resulting from the increasing proportion of non-regular employees thus has negative implications for equity. It also reduces long-term growth prospects by boosting the rate of worker turnover; $62 \%$ of non-regular workers have less than one year of tenure compared to $30 \%$ for regular workers. A number of studies show that non-regular workers receive less training than regular workers (Grubb et al., 2007).

66. The government's strategy is to limit the use of non-regular workers and prevent discriminatory treatment of them. The labour law reform bill passed in December 2006 had two major provisions:

- "Unjustifiable discriminatory practices" against non-regular workers are prohibited. Employees claiming discriminatory working conditions or wages can submit complaints to the Labour Relations Commission, where firms must prove that their practices are not discriminatory.

- After two years of employment, workers with fixed-term contracts are considered to be regular employees. However, the labour unions argue that the limit on fixed-term contracts is too long and that firms will simply fire such workers before the end of the two years.

In addition, the government plans to target active labour market policies on non-regular workers to improve their employability and increase the coverage of such workers by the social safety net.

29. The revision of the labour law in 1998 to allow collective dismissals for "urgent managerial reasons" has not sufficiently enhanced flexibility in practice. This reflects the attached conditions, notably exhausting "all means" to avoid dismissals, discussing proposed dismissals for at least two months with workers and notifying the government. In practice, rulings by the Supreme Court have introduced flexibility in certain cases. Nevertheless, given the constraints in the law, firms have relied on more expensive methods to reduce employment, such as early retirement packages and incentives for voluntary departures. In addition, regular workers in unionised companies also receive protection in collective bargaining agreements. 
67. The emergence of a dualistic labour market, in which one segment is subject to lower wages, less protection from the social safety net and greater job precariousness, creates equity concerns. While the labour law reform is aimed at reducing the growing proportion of non-regular workers, it risks reducing employment of such workers, as well as overall employment. The prohibition on discrimination against non-regular workers may subject firms to costly and time-consuming litigation that would discourage the employment of non-regular workers and increase poverty, thereby putting upward pressure on public social spending. If non-discrimination were interpreted as wage parity, the total wage bill would increase by as much as $13 \%$. In practice, the actual increase would depend on the proportion of the wage gap that is attributed to discrimination and how much is due to differences in the job performed and productivity, a question for which there is a wide range of estimates, as shown above.

68. Instead, relaxing employment protection for regular workers would reduce dualism and may spur job creation. It may also encourage investment in Korea (see the 2007 OECD Economic Survey of Korea). At the same time, it is important to improve the effective coverage of social insurance, including the Employment Insurance System (EIS), to reduce the gap in labour costs between regular and non-regular workers. In 2005, only $27 \%$ of unemployed persons received unemployment benefits, due in part to strict conditions to qualify for benefits as well as their relatively short duration. However, it was also because of the limited coverage of the EIS. Although nearly $80 \%$ of employees are eligible for the EIS, only $57 \%$ are actually insured (Table 16), reflecting the difficulty of ensuring compliance. Increasing the effective coverage is complicated by the frequent turnover of non-regular employees and the large number of small firms. Indeed, 3 million of Korea's 3.2 million firms in 2005 had less than ten employees. The initiative of the National Tax Service to require firms to report the payroll of temporarily employed workers and contingent employees may be helpful in improving compliance. In addition, the collection of the four social insurance contributions (pension, health, employment and industrial accident) will be consolidated in a single agency in 2009 .

Table 16. Coverage of the Employment Insurance System

Number of workers in thousands and per cent

\begin{tabular}{|c|c|c|c|c|c|c|c|c|}
\hline & 1995 & 1999 & 2000 & 2001 & 2002 & 2003 & 2004 & 2005 \\
\hline Wage and salary earners & 12824 & 12603 & 13142 & 13265 & 13932 & 14672 & 14584 & 15185 \\
\hline Eligible for EIS & 4280 & 8342 & 8700 & 9269 & 9269 & 9651 & 12389 & 12011 \\
\hline Actually insured & 4204 & 5876 & 6747 & 6884 & 7102 & 7180 & 7905 & 8663 \\
\hline Eligible as a per cent of wage & & & & & & & & \\
\hline $\begin{array}{l}\text { and salary earners } \\
\text { Insured as a per cent of }\end{array}$ & 33.4 & 66.2 & 66.2 & 69.9 & 66.5 & 66.0 & 84.9 & 79.1 \\
\hline eligible workers & 98.2 & 70.4 & 77.6 & 74.3 & 76.6 & 74.4 & 63.8 & 72.1 \\
\hline $\begin{array}{l}\text { Insured as a per cent of wage } \\
\text { and salary earners }\end{array}$ & 32.8 & 46.6 & 51.3 & 51.9 & 51.0 & 49.1 & 54.2 & 57.0 \\
\hline receiving benefits ${ }^{1}$ & . & 13.5 & . & 16.0 & $\cdots$ & 19.1 & 23.6 & 27.3 \\
\hline
\end{tabular}

1. Annual averages.

Source: Ministry of Labour.

\section{Conclusion}

69. Korea faces considerable pressure to increase public social spending on childcare, pensions, healthcare, long-term care and social assistance, as discussed above. However, the government should be cautious in boosting such spending, which may be difficult to reduce in the future. A number of OECD countries have found that significant increases in social spending, accompanied by higher taxes, have had a negative impact on economic growth. The pace of spending hikes should be consistent with targets to 
ensure medium and long-term fiscal sustainability and increased social spending should be partially offset by reduced outlays in other areas. Rather than setting an overall target of around $21 \%$ of GDP for social spending, it would be better to focus on developing effective programmes in each area that taxpayers are willing to fund, an objective of the Vision 2030 plan. For example, the proposed increase in the National Pension Scheme contribution rate to the $15.9 \%$ level necessary to ensure the financial sustainability of the scheme, assuming a 50\% replacement rate, was rejected by the National Assembly, and the political parties agreed to leave the contribution rate at its current level of $9 \%$. Specific recommendations in each area discussed in the paper are summarised in Box 6.

70. The authorities should take into account the characteristics of the labour market in developing the social safety net. Given the key role of social insurance programmes in Korea, about three-quarters of public social spending is financed by contributions from workers, and the other quarter by the government. The burden on workers is relatively high compared to the European Union, where the government financed $37 \%$ of public social outlays in 2001. Contribution-based social spending may have an effect comparable to tax-based systems, if the coverage is comprehensive. However, coverage is far from universal in Korea. As noted above, only half of the labour force contributes to the public pension scheme, reflecting a low proportion for the self-employed. Similarly, $64 \%$ of regular workers are insured by the EIS, but only $34 \%$ of non-regular workers. In addition, the difficulty of ensuring compliance and enhancing the transparency of the income of the self-employed places a large burden on employees, who account for $43 \%$ of the working-age population. Indeed, social insurance charges already amount to $25 \%$ of employee earnings (Table 17). Greater reliance on tax-financed social spending, such as the basic pension benefit, would reduce the burden on employees. In sum, it is important to design social spending programmes that are compatible with Korea's labour market characteristics.

Table 17. Social insurance contributions

Per cent of employee earnings in 2005

\begin{tabular}{|c|c|c|c|}
\hline & Employer & Employee & Total \\
\hline Industrial accident compensation insurance & 1.62 & $\ldots$ & 1.62 \\
\hline Wage claim guarantee fund & 0.04 & . & 0.04 \\
\hline Employment Insurance System ${ }^{1}$ & 1.30 & 0.45 & 1.75 \\
\hline National Health Insurance & 2.16 & 2.16 & 4.31 \\
\hline National Pension Scheme & 4.50 & 4.50 & 9.00 \\
\hline Retirement allowance ${ }^{2}$ & 8.30 & . & 8.30 \\
\hline Total & 17.92 & 7.11 & 25.02 \\
\hline
\end{tabular}

1. The rate varies from $0.7 \%$ to $1.3 \%$ depending on the size of the firm.

2. The Labour Standard Law requires firms to pay departing employees a lump-sum of one month of salary for every year worked.

Source: Ministry of Finance and Economy.

71. While increased social spending is one usual response to rising inequality and poverty, it is important to address the issue of increased dualism in the labour market. Reversing the trend toward more non-regular workers would reduce the need for additional social spending aimed at the working-age population. Moreover, an expansion of social programmes may not always succeed in substantially reducing poverty rates; between 1995 and 2000, there was only a weak relationship between increases in social spending and overall reductions in poverty in OECD countries (OECD, 2006b).

72. Finally, the emphasis on equality in the provision of social services should be tempered by more attention to promoting competition and enhancing consumer welfare. This would reduce the emphasis on the public provision of social services, such as childcare and long-term care, in favour of a larger role for private firms. Providing vouchers to users of services would stimulate competition and the supply of 
services that match consumer demands. In addition, allowing a greater role for private health insurance for services not covered by the NHI and for-profit hospitals would increase consumer welfare.

\section{Box 6. Summary of recommendations on public social spending in the context of ageing}

\section{Remove obstacles that limit the fertility rate}

- $\quad$ Reform the education system to reduce reliance on private tutoring institutions and lower the out-of-pocket cost paid by families for education.

- $\quad$ Reduce obstacles that discourage childbirth by ensuring an adequate supply of high quality childcare and encouraging more family-friendly policies in firms, an approach that will also boost female labour participation.

- Encourage private-sector supply of childcare, in part by removing price caps on private-sector suppliers.

- Be cautious in introducing tax and social benefits for families to boost the fertility rate as this approach may also discourage the labour force participation of women.

\section{Encouraging labour force participation}

- $\quad$ Address the factors that limit the attractiveness of the labour market to women by reversing the trend toward greater non-regular employment and the importance of seniority in determining wages.

- $\quad$ Promote the participation of older workers by raising or eliminating mandatory retirement ages.

- $\quad$ Replace employment subsidies with high deadweight costs by more emphasis on lifelong education.

\section{Ensuring adequate income for elderly persons}

- Increase the means-tested benefit from $5 \%$ of the average wage to reduce poverty among the elderly, given the difficulty in extending the coverage of the NPS.

- $\quad$ Reform the pension schemes for the civil service, military and private-school teachers to reduce government subsidies and introduce portability with the NPS.

- Accelerate the transition from the lump-sum retirement allowance to company pensions through changes in the tax law and promote the use of defined contribution rather than defined benefit schemes.

\section{Improving the healthcare system}

- Avoid overall cuts in co-payment rates to limit the rise in public healthcare expenditures.

- $\quad$ Lower the ceiling on the amount of co-payments over a six-month period in order to ensure greater access for low-income persons and patients with chronic illnesses.

- $\quad$ Mitigate the burden on the working-age population by requiring the elderly to contribute to the $\mathrm{NHI}$.

- $\quad$ Allow for-profit companies, including foreign firms, to provide healthcare and permit a greater role for private health insurance for services not covered by the $\mathrm{NHI}$ to increase the availability of high quality services.

- $\quad$ Limit spending pressures by making the unified $\mathrm{NHI}$ a more effective purchaser of health services and by considering payment systems other than fee-for-service.

- Promote "healthy ageing" to avoid longer periods of disability as life expectancy increases.

- Improve the framework for the provision of pharmaceuticals to reduce their relatively large share in healthcare spending. 
ECO/WKP(2008)23

\section{Providing long-term care for the elderly}

- Expand the capacity of long-term care facilities for the elderly, thus lowering the burden on the healthcare system.

- $\quad$ Reduce reliance on public-sector institutions by encouraging the entry of private-sector suppliers.

- Control the increase in demand for long-term care as insurance is introduced by ensuring an effective gatekeeping function and favouring home-based care over more expensive institutional care when possible.

\section{Addressing rising inequality and relative poverty}

- $\quad$ Expand the National Basic Livelihood Security System to ensure that all households have an income that at least matches the minimum cost of living.

- Increase the coverage of non-regular workers by the social insurance programmes for pensions, health and employment, thereby improving equity and reducing the cost advantage in hiring non-regular workers.

- Ensure that the new labour law provisions to prevent discrimination against non-regular workers do not discourage the hiring of such workers, which firms need for employment flexibility.

- Reduce employment protection for regular workers to reverse the rising proportion of non-regular workers. 


\section{BIBLIOGRAPHY}

Adema, Willem and Maxime Ladaique (2007), "Net Social Expenditure, 2006 Edition", OECD Social, Employment and Migration Working Paper (forthcoming), OECD, Paris.

Adsera, Alicia (2004), "Changing Fertility Rates in Developed Countries. The Impact of Labor Market Institutions, Journal of Population Economics, Vol. 17 (January).

Ahn, Joyup, Dong-Bae Kim and S.K. Lee (2003), Non-regular Workers and Policy Agenda III, Korea Labor Institute, Seoul (in Korean).

Ahn, Joyup (2006), "Nonstandard Work in Korea - the Origin of Wage Differentials", mimeo, Korea Labor Institute, Seoul.

Arjona, Roman, Maxime Ladaique and Mark Pearson (2001), "Growth, Inequality and Social Protection", OECD Labour Market and Social Policy Occasional Paper No. 51, OECD, Paris.

Bassanini, Andrea and Romain Duval (2006), "Employment patterns in OECD countries: reassessing the role of policies and institutions", OECD Economics Department Working Paper No. 486, OECD, Paris.

Chang, Jiyeun (2004), "Grants to Promote Employment of the Elderly in Korea - Introduction and Evaluation”, Korea Labor Institute Issue Paper No. 35, Seoul.

Cho, Nam-Hoon (2006), "New Challenges of Fertility and Family Policies in Korea", paper prepared for Policy Forum on Low Fertility and Ageing Society in Seoul, 13-14 September 2006.

Cho, Joonmo and Seung Gil Lee (2005), "Labour Market Reform: Issues for Employment Promotion of the Elderly", KDI Annual Report, Korea Development Institute, Seoul.

Choi, Sook-Hee (2005), "Coping with Low Fertility Rate", Economic Report, Samsung Economic Research Institute, Seoul.

D'Addio, Anna and Marco Mira d'Ercole (2005), "Trends and Determinants of Fertility Rates in OECD Countries: The Role of Policies", OECD Social, Employment and Migration Working Paper No. 6, OECD, Paris.

Dang, Thai Than, Pablo Antolin and Howard Oxley (2001), "Fiscal Implications of Ageing: Projections of Age-Related Spending", OECD Economics Department Working Paper No. 305, OECD, Paris.

Docteur, Elizabeth and Howard Oxley (2003), "Health-Care Systems: Lessons From the Reform Experience", OECD Economics Department Working Paper No. 374, OECD, Paris.

Förster, Michael and Marco Mira d'Ercole (2005), "Income Distribution and Poverty in OECD Countries in the Second Half of the 1990s", OECD Social, Employment and Migration Working Paper No. 22, OECD, Paris.

Government of Korea (2006), Seromachi Plan 2010, Seoul (in Korean). 
Grubb, D., J-K. Lee and P. Tergeist (2007), "Addressing Labour Market Duality in Korea”, OECD Social, Employment and Migration Working Paper, forthcoming, OECD, Paris.

Hwang, Soo Kyeong and Jiyeun Chang (2004), "Female Labor Supply and Labor Policies for Female Workers in Korea", Korea Labor Institute Issue Paper No. 30, Seoul.

Imai, Yutaka and Howard Oxley (2005), "Managing Public Costs in the Japanese Health- and NursingCare Sector", Conference on "Japan's Long-Term Fiscal Challenge”, 27-28 June 2005, Tokyo.

Jaumotte, Florence (2003), "Labour Force Participation of Women: Empirical Evidence on the Role of Policy and Other Determinants in OECD Countries", OECD Economic Studies, No. 37, 2003/2, OECD, Paris.

Jeong, Jin-Ho (2003), “Wages in Korea”, Korea Labor Institute Issue Paper No. 25, Seoul.

Jones, Randall S. and Tadashi Yokoyama (2008), "Reforming Housing and Regional Policies in Korea", OECD Economics Department Working Paper, forthcoming, OECD, Paris.

Jones, Randall S. and Taesik Yoon (2008), "Enhancing the Globalisation of Korea", OECD Economics Department Working Paper, forthcoming, OECD, Paris.

KIHASA (Korean Institute for Health and Social Affairs), Ministry of Health and Welfare and the Presidential Committee on Aging Society and Population Policy (2005), 2005 National Survey of Marriage and Childbirth Trends, (in Korean), Seoul.

KIHASA (Korean Institute for Health and Social Affairs) (2006), Living Proflies of Older Persons and Social Policies on Ageing in Korea, Seoul.

Kim, Hyunjin (2004), "Analysing the Effects of the High School Equalisation Policy and the College Entrance System on Private Tutoring Expenditure in Korea", Journal of Educational Policy, Vol. 1, No. 1, Korean Educational Development Institute, Seoul.

Kim, Taejong (2004), "Shadow Education: School Quality and Demand for Private Tutoring in Korea", KDI School of Public Policy and Management, mimeo, Seoul.

Korea Employers Federation (2006), 2006 Industrial Relations and Labour Market of Korea, Seoul.

Korea National Statistical Office (2006), Social Statistics Survey, Seoul.

Ku, I. (2004), "Poverty in Korea, Why It Remains Higher?" Korean Journal of Social Welfare, Vol. 56, No. 4, (in Korean).

Kwon, Soonman (2006), "Population Aging, Medical Expenditure and Long-term Care Reform in Korea," Korean Social Security Review (22: 2), (in Korean).

Kwon, Tai-Hwan (2003), "Demographic trends and their social implications", Social Indicators Research, Vol. 62.

Lundsgaard, Jens (2005), "Consumer Direction and Choice in Long-Term Care for Older Persons, Including Payments for Informal Care: How Can it Help Improve Care Outcomes, Employment and Fiscal Sustainability?", OECD Health Working Paper, No. 1, OECD, Paris. 
Martin, John and David Grubb (2001), "What works and for whom: a review of OECD countries' experience with active labour market policies", Swedish Economic Policy Review.

Ministry of Health, Labour and Welfare (2006), Overview of the Revision of the Long-term Care Insurance System, Tokyo.

Moon, Hyungpyo (2006), "Population Aging and Sustainability of the National Pension System", mimeo, Korea Development Institute, Seoul.

Na, Jung and Mugyeong Moon (2006), Early Childhood Education and Care Policies in the Republic of Korea, OECD Thematic Review of Early Childhood Education and Care Policy: Background Report, OECD, Paris.

National Federation of Health Insurance Societies (Kemporen) (2006), Health Insurance, Long-Term Care Insurance and Health Insurance Societies in Japan, 2006, Tokyo.

National Pension Service (2006), National Pension Statistical Yearbook, Seoul.

OECD (2003), Reviews of Health Care Systems: Korea, OECD, Paris.

OECD (2004), Ageing and Employment Policies: Korea, OECD, Paris.

OECD (2005a), Long-term Care for Older People, OECD Health Project, OECD, Paris.

OECD (2005b), OECD Economic Survey of Korea, OECD, Paris.

OECD (2006a), OECD Economic Survey of Australia, OECD, Paris.

OECD (2006b), OECD Economic Survey of Japan, OECD, Paris.

OECD (2006c), Employment Outlook, OECD, Paris.

OECD (2006d), "Projecting OECD Health and Long-Term Care Expenditures: What are the Main Drivers?" OECD Economics Department Working Paper No. 477, OECD, Paris.

OECD (2006e), Society at a Glance: OECD Social Indicators, OECD, Paris.

OECD (2006f), Starting Strong II: Early Childhood Education and Care, OECD, Paris.

OECD (2007a), Facing the Future: Korea's Family, Pension and Health Policy Challenges, OECD, Paris.

OECD (2007b), OECD Economic Survey of Korea, OECD, Paris.

Park, C., S. Kang and T. Kim (2002), Analysis of trends and contributing factors in income distribution and poverty, Korea Institute for Health and Social Affairs, Seoul.

Park, Neung-Hoo (2005), "Korea's Poverty Reduction Programs: with Special Reference to the National Basic Livelihood Security System,” APEC SSN Symposium, 23-24 August 2005, Seoul.

Pearson, Mark and John Martin (2005), "Should We Extend the Role of Private Social Expenditure?" OECD Social, Employment and Migration Working Paper No. 23, OECD, Paris. 
Saidel, Andrew (2004), “Japan's Long-term Care Insurance System Faces Overhaul: Straining to Meet Demand, Lawmakers Set to Make Changes", Policy \& Research, AARP.

Shimizutani, Satoshi (2006), “Japan's Long-term Care Insurance Program: An Overview”, Swiss Journal of Economics and Statistics, Vol. 142.

World Bank (2007), World Development Indicators, forthcoming, Washington.

Yeo, Y., M. Kim, T. Kim, S. Yang and H. Choi (2005), An Analysis of Trends and Contributing Factors for Poverty and Inequality, Korea Institute of Health and Social Affairs, Seoul.

Yun, Sukmyung (2005), "Rapid Ageing and Old-age Income Security in Korea - with Special Reference to the NPS", mimeo. 


\section{WORKING PAPERS}

The full series of Economics Department Working Papers can be consulted at www.oecd.org/eco/Working_Papers/

614 Enhancing the globalisation of Korea

(May 2008) Randall S. Jones and Taesik Yoon

613. Reforming housing and regional policies in Korea

(May 2008) Randall S. Jones and Tadashi Yokoyama

612. Moving towards more sustainable healthcare financing in Germany

(May 2008) N. Brandt

611. Improving education outcomes in Germany

(May 2008) David Carey

610. Have developed countries escaped the curse of distance?

(May 2008) Hervé Boulhol and Alain de Serres

609. Measures of international transport cost for OECD countries $\backslash$

(April 2008) Stephen S. Golub and Brian Tomasik

608. Encouraging labour force participation in Chile

(April 2008) D. Contreras, L. de Mello and E. Puentes

607. Tackling business and labour informality in Chile

(April 2008) D. Contreras, L. de Mello and E. Puentes

606. Delivery cost-efficient public services in health care, education and housing in Chile (April 2008) D. Contreras, L. de Mello and E. Puentes

605. Managing Chile's macroeconomy during and after the copper price boom (April 2008) Luiz de Mello

604. Avoiding the value added tax: Theory and cross-country evidence (April 2008) Luiz de Mello

603. Oil Price Shocks, Rigidities and the Conduct of Monetary Policy: Some Lessons from a New Keynesian Perspective (April 2008) Romain Duval and Lukas Vogel

602. The Contribution of Economic Geography to GDP Per Capita (April 2008) Hervé Boulhol, Alain de Serres and Margit Molnar

601. Estimating a supply block for Poland

(April 2008) Rafal Kierzenkowski, Patric Ollivaud, Franck Sédillot and Philippe Briard

600. Product market regulation and economic performance across Indian states (March 2008) Paul Conway, Richard Herd and Thomas Chalaux 
599. Improving product market regulation in India: an international and cross-state comparison (March 2008) Paul Conway and Richard Herd

598. Revenue buoyancy and its fiscal policy implications (February 2008) Isabelle Joumard and Christophe André

597. Monetary policy, market excesses and financial turmoil (February 2008) Rudiger Ahrend, Boris Cournède and Robert Price

596. Explaining differences in hours worked among OECD countries: an empirical analysis (February 2008) Sven Blondal and Jean-Marc Burniaux

595. Fiscal policy in India: past reforms and future challenges (February 2008) Richard Herd and Willi Leibfritz

594. The significance of Switzerland's enormous current-account surplus (March 2008) Peter Jarrett and Céline Letremy

593. Interdependencies between monetary policy and foreign-exchange intervention under inflation targeting: the case of Brazil and the Czech Republic

(January 2008) Jean-Yves Gnabo, Luiz de Mello and Diego Moccero

592. Solow or Lucas? Testing growth models using panel data from OECD countries (December 2007) Jens Arnold, Andrea Bassanini and Stefano Scarpetta

591. The private internal rates of return to tertiary education: new estimates for 21 OECD countries (December 2007) Romina Boarini and Hubert Strauss.

590. Making federalism work (December 2007) Alexandra Bibbee

589. The wage premium on tertiary education: New estimates for 21 OECD countries (December 2007) Hubert Strauss and Christine de la Maisonneuve

588. Enhancing the benefits of financial liberalisation (March 2007) Stefan Ide, Jens Høj and Patrick Lenain

587. Improving incentives in tertiary education (March 2007) Jens Høj

586. Globalisation and the European Union: which countries are best placed to cope? (December 2007) David Rae and Marte Sollie

585. Primary and secondary education in the United States (November 2007) Peter Tulip and Gregory Wurzburg

584. Financing higher education in the United States (November 2007) Peter Tulip

583. Corporate net lending: a review of recent trends (November 2007) Christophe André, Stéphanie Guichard, Mike Kennedy and David Turner 